\title{
Reduce and Control: A Combinatorial Strategy for Achieving Sustained HIV Remissions in the Absence of Antiretroviral Therapy
}

\author{
Roland Schwarzer, Andrea Gramatica ${ }^{\dagger}$ and Warner C. Greene* \\ Gladstone Institute of Virology and Immunology, Departments of Medicine, Microbiology \& Immunology, \\ University of California, San Francisco, CA 94158, USA; roland.schwarzer@gladstone.ucsf.edu (R.S.); \\ andrea.gramatica@gladstone.ucsf.edu or ang4015@med.cornell.edu (A.G.) \\ * Correspondence: warner.greene@gladstone.ucsf.edu \\ + Current address: Weill Cornell Medicine, New York, NY 10021, USA.
}

Received: 11 January 2020; Accepted: 5 February 2020; Published: 8 February 2020

\begin{abstract}
Human immunodeficiency virus (HIV-1) indefinitely persists, despite effective antiretroviral therapy (ART), within a small pool of latently infected cells. These cells often display markers of immunologic memory and harbor both replication-competent and -incompetent proviruses at approximately a 1:100 ratio. Although complete HIV eradication is a highly desirable goal, this likely represents a bridge too far for our current and foreseeable technologies. A more tractable goal involves engineering a sustained viral remission in the absence of ART-a "functional cure." In this setting, HIV remains detectable during remission, but the size of the reservoir is small and the residual virus is effectively controlled by an engineered immune response or other intervention. Biological precedence for such an approach is found in the post-treatment controllers (PTCs), a rare group of HIV-infected individuals who, following ART withdrawal, do not experience viral rebound. PTCs are characterized by a small reservoir, greatly reduced inflammation, and the presence of a poorly understood immune response that limits viral rebound. Our goal is to devise a safe and effective means for replicating durable post-treatment control on a global scale. This requires devising methods to reduce the size of the reservoir and to control replication of this residual virus. In the following sections, we will review many of the approaches and tools that likely will be important for implementing such a "reduce and control" strategy and for achieving a PTC-like sustained HIV remission in the absence of ART.
\end{abstract}

Keywords: HIV; cure; block and lock; shock and kill; genome editing; reduce and control

\section{Introduction}

The history of human immunodeficiency virus (HIV-1)/acquired immunodeficiency syndrome (AIDS) is a story of initial fear and panic followed by rapid, frankly stunning, scientific and medical progress [1]. Since the 1983-1984 discoveries of the human immunodeficiency virus (HIV-1) [2] and its etiologic linkage to the acquired immunodeficiency syndrome (AIDS) [3-5], this virus has been extensively dissected, its pathogenic mechanisms defined, and the host's defensive immune responses well characterized. This deep understanding of the virus accelerated development of antiretroviral therapy (ART) principally targeting the major enzymes of the virus. Now, more than 30 different antiretroviral drugs are available. With access to and compliance with these drugs, viremia in essentially every HIV-infected individual can now be suppressed to undetectable levels. These therapeutic advances will be recorded as a true milestone in the history of modern medicine.

However, despite this progress, we still do not have an effective prophylactic vaccine for the uninfected, or a safe and scalable cure for those already infected. Currently, over 37.9 million people are HIV-positive (UNAIDS 2019 report). Due in large part to the heroic efforts within programs 
like PEPFAR (https://www.hiv.gov/federal-response/pepfar-global-aids/pepfar) and the Global Fund (https://www.theglobalfund.org/en/), 23 million infected people are now receiving life-saving ART throughout the world including developing countries, where most new infections are occurring. However, the multi-billion-dollar annual investment by the developed countries required to fund daily ART in the developing world is becoming increasingly uncertain due to multiple factors, including AIDS fatigue among donors and changing international priorities. Those not currently being treated will undoubtedly prove the hardest to reach in future efforts. A safe, effective and scalable HIV cure would be medically and financially transformative for the world, and would certainly help sub-Saharan Africa bring a close to its long struggle against HIV/AIDS.

\subsection{HIV Latency and the Latent Reservoir}

Following entry into CD4-expressing target cells, HIV-1 integrates into the host genome, establishing the HIV provirus. Two fates are possible for infectious proviruses: i) productive infection with spread of virions to new cellular targets or ii) establishment of latency characterized by little or no expression of viral proteins. Of note, most latent HIV proviruses are defective [6,7]. For every infectious HIV provirus there are at least 100, if not more, defectives present [8]. Although these defective viruses do not give rise to infectious progeny, they can produce inflammation through the intermittent production and release of viral RNA and proteins [7,9], including novel, unspliced RNA species as well as chimeric HIV proteins [10]. Increased inflammation favors further spread of infectious virus [11]. The relative lack of inflammation found in post-treatment controllers may play a special role in their ability to control spread of the virus.

In blood, latent proviruses are primarily found in central, transitional, and effector memory CD4 $\mathrm{T}$ cells as well as in T-follicular helper (Tfh) cells and, to a lesser extent, in CD4 T stem memory cells (Tscm) [12,13] and hematopoietic stem and progenitor cells (HSPCs) [14]. The self-renewing properties of Tscm and HSPCs could play a key role in reservoir maintenance while lymphoid follicles, where Tfh cells primarily reside, could provide a site of relative immune privilege for infected reservoir cells due to reduced ingress of cytotoxic T lymphocytes (CTLs) [15-17].

With few exceptions [18-20], most studies of latency in HIV-infected individuals have involved the analysis of blood [21]. Going forward, it will be important to compare and contrast properties of HIV latency found in lymphoid tissue versus blood, but this will require better access to tissue [22]. Effector memory $\mathrm{T}$ cells may play an especially prominent role as cellular hosts for the latent reservoir in tissues [23].

Within the myriad of memory $\mathrm{T}$ cell subsets, multiple factors impact whether the virus is latent or not. These include the site of proviral DNA integration [24-30], the low abundance, or cytoplasmic sequestration, of key cellular transcription factors in resting cells [31], the presence of repressive epigenetic modifications [32-35], impaired RNA splicing [36] and decreased nuclear export, and the reduced translation of these viral RNAs [37]. One newly described mechanism through which HIV helps ensure its own latency involves the action of its antisense transcript (AST) generated within the 3' LTR. AST binds to complementary sequences in the 5' LTR and, like long non-coding RNAs, can promote recruitment of the Polycomb Repressor Complex 2 (PRC2) and induction of silencing through trimethylation of lysine 27 on the $\mathrm{H} 3$ histone (H3K27me3) [38].

\subsection{Post-Treatment Control: A Blueprint for "Reduce and Control?"}

Although almost all HIV-infected persons experience rapid viral rebound following ART interruption, rare individuals $(<10 \%$, [39,40]) exhibit sustained virologic suppression and persistently high CD4 $\mathrm{T}$ cell counts for months or years after treatment cessation. These "post-treatment controllers" (PTCs) [41-43] illustrate that it is possible to establish durable HIV control after infection. While the exact mechanism operating in PTCs is unclear, these individuals have a small reservoir [44], a low degree of inflammation, and relatively weak HIV-specific CTL activity [42,45]. Of note, recent interest has focused on the potential role of NK cells in PTC. For example, Pohlmeyer et al. have identified 
CD11b+, CD57-, CD161+, Siglec7+ subpopulations of CD56dim, CD16+ NK cells that are prominent in HIV controllers but not in HIV non-controllers [46].

Most of the approaches now in the clinic seek to achieve long-term control of a replication-competent reservoir (a "sustained viral remission"). PTCs appear to represent natural examples of the implementation of an effective "reduce and control" strategy [41]. We urgently require a better understanding of the molecular and immunological basis for post-treatment control.

\subsection{An Overview of HIV Cure Approaches}

The first attempts to eliminate the latent reservoir focused on earlier and intensified use of ART. However, this approach has proven ineffective [47], in part because the reservoir is formed so quickly [48,49] and remains stable for so long [50,51]. Additionally, latent HIV proviruses are not adversely affected by ART. It became clear that novel therapeutic strategies were necessary to attack the latent reservoir.

In the following sections, we provide an overview of many of the major HIV-1 cure strategies currently being pursued (Figure 1). First, we consider the existing immune-based approaches and then specifically focus on two complementary but not necessarily mutually exclusive strategies--"shock and kill" [52] and "block and lock" [53]. Both of these approaches could form important components of an overall "reduce and control" strategy aimed at recapitulating post-treatment control. Finally, we consider recent efforts to apply gene editing technologies to HIV cure efforts.

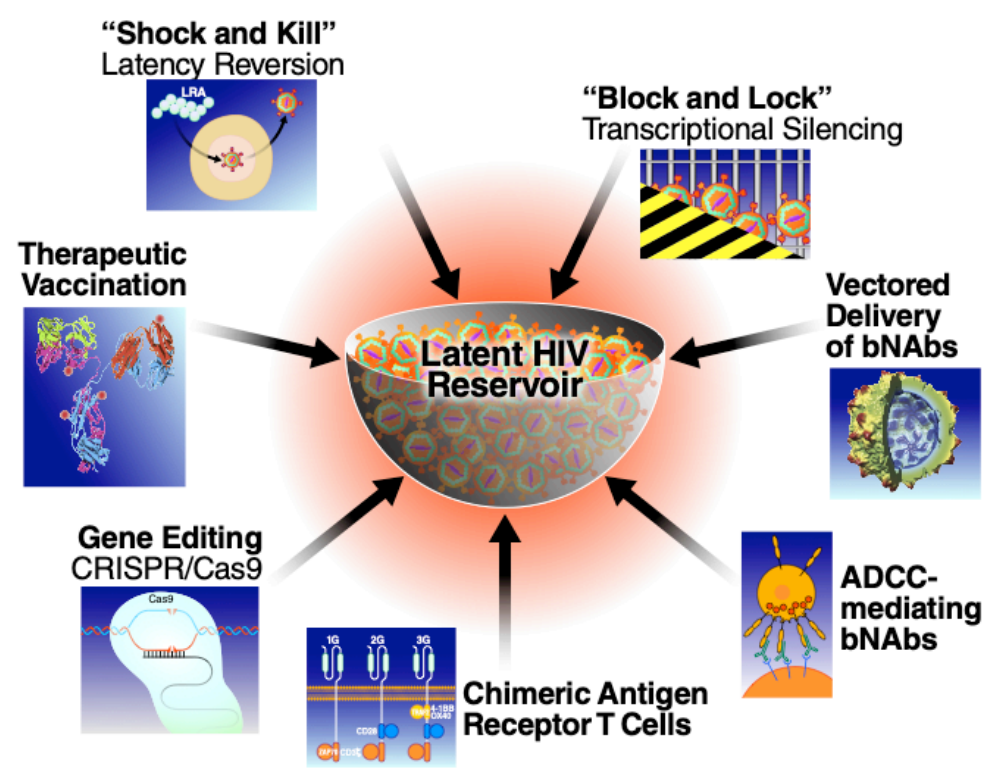

Figure 1. Therapeutic approaches being explored aimed at long term neutralization of the latent HIV reservoir. (bNAbs, broadly neutralizing HIV antibodies; ADCC, antibody dependent cellular cytotoxicity).

\subsection{Facilitating Immunological Control of HIV Infections}

One example of an immune-based treatment for HIV infections is a therapeutic vaccine. In contrast to their preventive counterparts, therapeutic vaccines are not administered preemptively, but rather after infection has occurred. As such, a therapeutic vaccine must elicit a different or stronger type of immune response than typically occurs as a result of natural infection. A successful therapeutic vaccine could suppress viral replication and spread so effectively as to prevent viral rebound after discontinuation of ART [54]. Therapeutic HIV vaccines have had a generally disappointing record, likely in part due to the fact that early candidates did not induce sufficiently broad responses to control viral escape mutants. More promising results are now emerging in primate studies incorporating 
rigorous analytical treatment interruptions as a measure of vaccine effectiveness [55-57]. Combining an effective therapeutic vaccine with an agent(s) capable of reducing reservoir size could enable a successful "reduce and control" strategy.

Another novel technology that seeks to facilitate immunological control of HIV-1 is the long-term expression of broadly neutralizing antibodies (bNAbs) delivered by viral vectors [58]. Multiple animal and human studies support the therapeutic potential of this approach, which would also render adherence issues moot. Nevertheless, long-term expression of bNAbs based on a vector-mediated gene transfer is, as technology, in its infancy. One concern with this method is the induction of anti-idiotypic immune responses against the humanized antibodies or immune responses to components of the viral vector [58]. Additionally, some classes of bNAbs recognizing glycan epitopes within Env have recently been shown to interact with uninfected cells, and thus could elicit unexpected and unwanted long-term toxicity [59].

bNAbs also can induce strong antibody-dependent cell cytotoxicity (ADCC) through interactions with $\mathrm{FcR} \gamma$ on natural killer cells. Clinical data show that the presence of antibodies that trigger ADCC is correlated with slower disease progression and reduced mortality [60]. Moreover, non-neutralizing antibodies mediating ADCC were identified as a correlate of protection in the RV144 HIV vaccine trial [61]. On the therapeutic front, passive administration of two bNAbs soon after infection of rhesus macaques with simian/human immunodeficiency virus (SHIV) was found to produce a potent CD8 T cell immune response that in 4 of 13 animals suppressed viremia for more than 2 years [62]. However, an open-label clinical trial involving administration of the VRC01 bNAb did not lead to persistent viral suppression following treatment interruption, although a delay in the time to viral rebound was observed [63]. Additional studies are required to more fully define the biological effects of bNAb administration in vivo.

Recently, chimeric antigen receptor T cells (CAR-T cells) received FDA approval for the treatment of acute lymphoblastic leukemia and non-Hodgkin's lymphoma [64,65]. Several studies, underway or recently published [66-68], are exploring CAR-T cells as a strategy to target HIV-1-infected cells. This technology is also in its infancy but holds great promise as a means to clear virus-infected cells, with minimal or no off-target effects. Due to their high specificity and long survival, CAR-T cells could in theory curb viral replication and spread in infected individuals, thus enabling both a reduction in reservoir size and the control of residual virus production. However, this approach is currently too expensive for broad-scale use. One the other hand, the CAR-T strategy will become more practical, markedly less expensive, and potentially scalable when universal allogeneic donor cells become available.

\section{In Vitro and In Vivo Reactivation of Latent HIV}

To eliminate latently infected cells, one approach is to activate expression of the latent virus under the cover of ART. These virus-expressing reservoir cells then either die due to (i) a viral cytopathic effect, as occurs in primary infection, or (ii) immune cell clearance triggered by their acquisition of "immunological visibility". Key to implementing the "reduce and control" strategy is the availability of safe and effective latency-reversing agents (LRAs) to accelerate reservoir reduction. Unfortunately, most of the current crop of LRAs are plagued with problems of potency and/or toxicity [69]. Further, these agents only activate a small fraction of the responsive reservoir cells [70], and necessitate repeated administration. The field urgently needs to identify LRAs with greatly improved properties. In the following section, we review the major classes of LRAs (Figure 2) that have been explored in pre-clinical as well as early clinical studies, discussing both their favorable and adverse properties. 


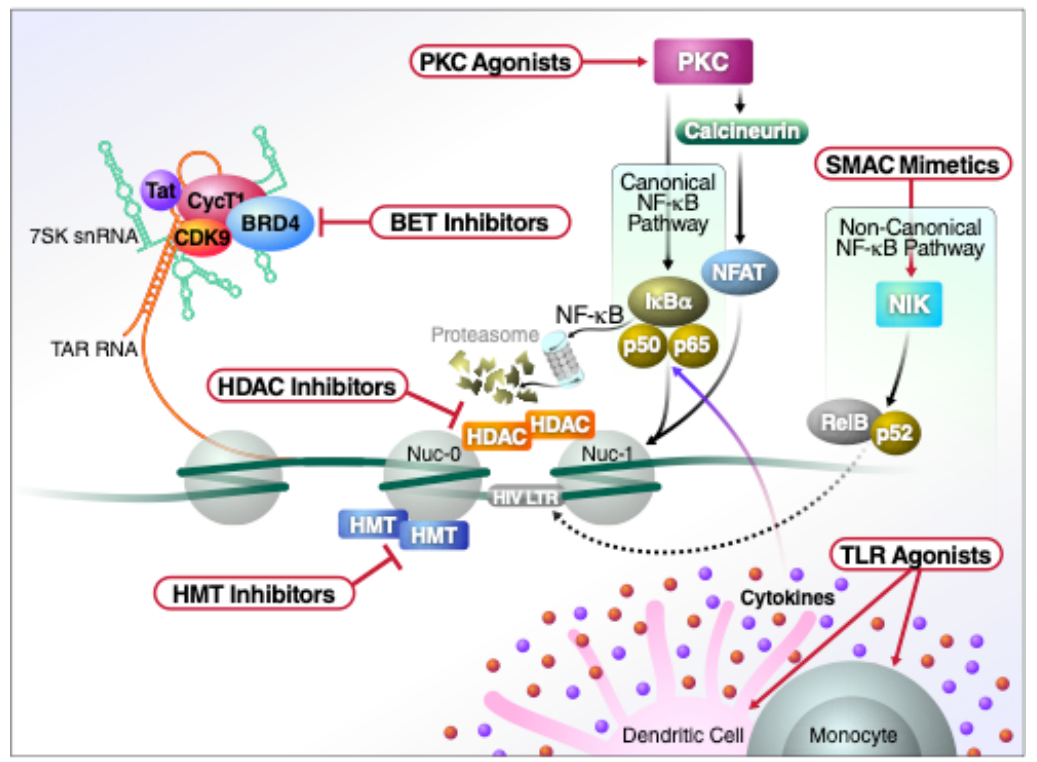

Figure 2. Schematic representation of the major classes of LRAs and their molecular mechanism of action.

\subsection{Histone Deacetylase (HDAC) and Histone Methytransferase (HMT) Inhibitors}

In latent reservoir cells, HIV transcription is silenced by a combination of epigenetic mechanisms mediated by histone deacetylases and histone methyl-transferases. Inhibitors of these enzymes are capable of activating HIV provirus expression in a variety of cell line models as well as in primary CD4 T cell models of latency, emphasizing a role for epigenetic control of viral latency [71-73]. HDAC inhibitors (e.g., valproic acid, vorinostat, and more recently panobinostat and romidepsin) have been tested as single agents in chronically infected individuals on ART [72,74]. However, although spikes in plasma viremia were detectable, no significant changes occurred in the size of the reservoir. Although disappointing, this outcome is perhaps not surprising because: (1) the site of chromosomal integration can affect HIV proviral responses to various agents in vitro, and (2) the more potent HDAC inhibitors directly impair CD8+ T cell and natural killer (NK) effector cell function, reducing clearance of reactivated reservoir cells $[75,76]$. Of note, vorinostat has been reported to not compromise CTL activity [77]. HMT inhibitors have also been investigated as potential LRAs. Chaetocin, BIX-01294 [78], UNC-0638 [34], AZ391 [79] all reverse latency in cultures of CD4 T cells isolated from HIV positive donors on suppressive ART, but issues of toxicity and potency diminish overall enthusiasm for this class of LRAs $[33,80]$.

\subsection{BET Inhibitors}

The bromo- and extra-terminal domain (BET) inhibitors induce reactivation of latent HIV by inhibiting BRD4, a protein that blocks LTR transcription elongation by preventing the $\mathrm{pTEFb}$ complex from binding to Tat [81]. The BET inhibitors also act by selectively binding to and inhibiting the action of the short form of BRD4 (BRD4s) that functions as an HIV corepressor [82]. Specifically, BRD4s directly binds to BRG1, a component of the BAF SWI/SNF chromatin remodeling complex. BET inhibitors negate the repressive effect of this remodeling complex, leading to increases in HIV transcription. The BET inhibitors alone often produce only weak and slowly evolving effects. However, these agents can synergize with PKC activators and they do not compromise cytotoxic effector function [83].

\subsection{Disulfiram}

Disulfiram was identified in a large drug screen as a potential LRA when assayed in a primary CD4 T cell model of HIV latency [84]. Disulfiram is an FDA-approved drug (Antabuse) used in the 
management of chronic alcoholism. It acts by inhibiting the phosphatase and tensin homolog (PTEN), leading to activation of the Akt pathway and induction of nuclear NF- $\kappa B$-expression [85]. These effects occur in the absence of broad-scale cytokine production or expression of cellular activation markers. Disappointingly, the promising in vitro effects of disulfiram were not confirmed in vivo. While well tolerated, only modest increases in viral RNA were detected $[86,87]$. When combined with other LRA classes (e.g., PKC agonists or HDAC inhibitors), no synergy was observed [83].

\subsection{PKC Agonists}

Activation of protein kinase C (PKC) initially attracted considerable attention as a mechanism to reverse HIV latency in vitro. PKC agonists, such as prostratin, bryostatin-1 or various ingenol compounds appear among the most potent LRAs, especially when combined with HDAC inhibitors $[83,88]$. In terms of their effects on HIV latency, bryostatin-1 and prostratin are the best characterized compounds in this group. However, because of their intrinsic toxicity, clinical investigations of bryostatin-1 and other PKC agonists have been slow to progress. When tested in vivo, bryostatin did not obviously alter the transcription of latent HIV at the single low dose tested [89]. As noted, required doses of the PKC activator can be reduced when combined with various synergizing agents including panobinostat, romidepsin, and vorinostat [90]. Such combination strategies could be tested in vivo but their overall toxicity combined with the effects on cytotoxic effector cells and the small fraction of cells activated by each dose dampens overall enthusiasm.

Ingenols are compounds isolated from the Euphorbia family of plants [70]. Ingenol-3,20-dibenzoate exhibits anti-leukemic properties in vitro [91]. Chemically engineered ingenols exhibit latency-reversing activity [92]. For example, Ingenol-3-mebutate, now approved by the FDA as a topical therapy for actinic keratosis, reactivates latent HIV at nanomolar concentrations with minimal CD4 T cell activation/toxicity or release of IFN $\gamma[93,94]$. Another ingenol, Ingenol B has been used in combination with the HDAC inhibitor vorinostat to treat SIV-infected pigtail macaques previously suppressed with ART for 400 days. SIV viral load increases were observed in both plasma and the CSF with distinct viruses emanating from these two compartments [95]. Of note, it is unclear whether "shock and kill" approaches can be deployed to attack virus residing in the human CNS reservoir. This approach might simply be too toxic for the neurons intertwined with microglia harboring latent virus. Of note, these LRAs also alter properties of the blood-brain barrier increasing its permeability and allowing trafficking of proinflammatory cells that might paradoxically propel viral seeding of the CNS [96].

Ingenol-3-angelate (also known as PEP005) is yet another member of this family approved for the treatment of actinic keratoses [94]. Ingenol-3-angelate also reactivates latent HIV through the induction of NF-кB both alone and in a modestly synergistic manner with JQ1 in vitro [97]. Other ingenol compounds, like extracts from Euphorbia kansui, are currently being tested in human clinical trials for HIV latency-reversing activity (see NCT02531295). Kansui is an herbal supplement that has been prescribed for thousands of years in traditional Chinese medicine, often consumed as a tea. The first clinical trial of kansui as a latency-reversing agent in HIV-infected individuals was projected to complete in December 2020 but no results have yet been reported.

\subsection{Toll-like Receptor (TLR) Agonists}

TLRs correspond to membrane receptors that recognize conserved pathogen-associated molecular patterns (PAMPs) comprised of lipids, proteins, RNA/DNA or carbohydrates present in various bacterial, viral, fungal or protozoan pathogens [98]. These TLRs play a key role in initiation of the innate immune response. After binding to their ligands, the TLRs commonly induce activation of NF- $k B$, AP1 and various interferon regulatory factors (IRFs). Many TLR agonists are now being evaluated as potential LRAs, with agonists of TLR3, TLR7 and TLR9 already advancing into human trials [99]. MGN1703, a TLR9 agonist, induced HIV plasma RNA in 6 of 15 study participants concomitant with increased activation of NK and CD8 T cells, but no reduction in latent reservoir size was observed [100]. Dual TLR2 and TLR7 agonists such as CL413 have shown potent NF-kB-mediated HIV-1 reactivation 
that unfortunately is also accompanied by proinflammatory release of TFN $\alpha$ [101]. In rhesus macaques infected with simian immunodeficiency virus (SIV) and in HIV-infected individuals, both on ART, the administration of the TLR7 agonists GS-986 and GS-9620 led to significant increases in plasma SIV and HIV RNA, respectively, consistent with latency reversal [102,103]. These TLR agonists are also being tested in combination with various therapeutic vaccines. For example, the combination of TLR7 agonist with an AD26/MVA-based therapeutic vaccine led to improved control of rebound viremia when antiretroviral therapy was discontinued in SIV-infected rhesus macaques [104]. The combination of agents was significantly better than either of the single agents alone. Similarly, combining a TLR7 agonist and a V3 glycan-directed broadly neutralizing HIV antibody resulted either in no rebound or a delayed rebound in SHIV-infected macaques taken off ART [105].

\subsection{SMAC Mimetics}

Agents mimicking the action of the second mitochondria-derived activator of caspases, termed SMAC mimetics [106], both activate latent virus and cause HIV-infected cells to die. Other LRAs lack these dual properties. The SMAC mimetics principally activate the non-canonical NF- $\mathrm{KB}$ pathway. In contrast to classical or canonical NF- $\mathrm{kB}$ activation, the non-canonical pathway produces a slower and longer-lasting transcriptional activation often triggered through a subset of tumor necrosis factor receptors (TNFRs). In complex with cIAP2, TRAF2, and TRAF3, cIAP1 naturally degrades NF-кB-inducing kinase (NIK), preventing p100 processing into p52 [107]. SMAC mimetics induce degradation of cIAP2 via ubiquitylation and proteasome-mediated degradation. When cIAP2 is degraded, NIK expression stabilizes, allowing this kinase to phosphorylate and promote proteasomal processing of the NFKB2 gene product p100, yielding p52. p52 and its associated Rel protein partner, RelB, then rapidly translocate into the nucleus. Beyond cIAP2, the SMAC mimetics also promote degradation of several other survival factors including BIRC2, BIRC5 (survivin), XIAP and cIAP1 [108-110].

SMAC mimetics can also lead to activation of the canonical NF- $k B$ pathway. Accumulation of NIK ultimately leads to phosphorylation and degradation of inhibitor of $\kappa \mathrm{B}$ kinase $(\mathrm{I} \kappa \mathrm{B} \alpha)$, which in turn allows nuclear translocation of the prototypical NF-кB heterodimer p55/RelA] [111].

Among the SMAC mimetics tested thus far, SBI-0637142 and LCL161 are able to downregulate BIRC2, leading to proviral transcription [111]. Interestingly, the SMAC mimetic SBI-0637142 produces synergistic induction of HIV expression when combined with HDAC inhibitors, and induces apoptosis within latently infected CD4+ T cells where viral replication has been reactivated [112]. Three different SMAC mimetics including birinapant, GDC-0152, and a benzolactam-related compound, BL-V8-310, were shown to induce this selective cell death within HIV-1 infected central memory CD4 T cells [113]. In a related series of studies, in vitro treatment of infected cultures with the pro-apoptotic drug Venetoclax, which blocks Bcl-2 function, promoted the rapid death of productively infected primary $\mathrm{T}$ cells in vitro and a reduction of the latent reservoir in vitro following anti-CD3/CD28 stimulation of the cultures [114].

\subsection{Summary and Conclusions}

Since initial attempts to attack the reservoir using "shock and kill" began nearly ten years ago [71], this approach has proved disappointing for a number of reasons: (1) the initial LRAs tested either lacked potency or exhibited unacceptably high levels of toxicity both in vitro and in vivo $[115,116] ;(2)$ after a single dose, the tested LRAs only reactivate a small fraction of cells within the latent reservoir [70,117], indicating that serial administration of the agent will be required, placing toxicity issues front and center; (3) HIV can establish viral reservoirs in the central nervous system (CNS) [118], where certain LRAs may not enter, and "shock and kill" strategies may simply be too toxic for neuronal survival; and (4) CD8 T cells in HIV-infected individuals display markers of cell exhaustion and immune dysfunction that are accentuated by various LRAs, leading to a compromised ability to clear reactivated reservoir cells [119]. Clearly, the current crop of LRAs are not up to the task. An ideal LRA will activate a 
substantial fraction of the latent reservoir but at the same time exhibit a strong safety profile allowing for repeated dosing without excessive T cell activation or cytokine release. Drug combinations yielding synergistic effects will likely be required especially if latency is multifactorial and different LRAs hit different points of viral repression. The lack of highly active and safe LRAs represents a major deficit in HIV cure research and is undermining our ability to implement the "reduce and control" strategy. Of all of the LRAs thus far studied, SMAC mimetics appear the most promising. Their ability to both activate viral gene expression and to preferentially induce apoptosis in these virus-expressing reservoir cells is unique (a single agent that both "shocks" and "kills"). The question is whether these drugs can be given over a long term. Some dose-limiting toxicities including cytokine release syndrome has been observed in a small subset of treated cancer patients. Other side effects described include fatigue, nausea, vomiting, diarrhea and anorexia [120].

\section{3. "Block and Lock": An Alternative Strategy for A Functional Cure}

Because of the noted limitations with the current collection of LRAs, new approaches for neutralizing latent HIV proviruses must be actively explored. One such strategy, termed "block and lock" is conceptually the converse of "shock and kill". The goal in "block and lock" is to permanently silence the transcriptional activity of the virus, thereby allowing safe withdrawal of ART. Precedent for such neutralization is found with the human endogenous retroviruses (HERVs) that occupy approximately $7 \%$ of the human genome [121]. Although some of these HERVs are rendered non-functional by crippling mutations within their open-reading frames, many are silenced through histone trimethylation, DNA methylation and RNAi -dependent pathways [122]. Importantly, it might be possible to deploy these same mechanisms to permanently silence integrated HIV proviruses, thereby neutralizing the latent reservoir.

Such "block and lock" approaches have conceptual advantages over "shock and kill". The latter carries the risk of reservoir expansion if kill mechanisms are not effective, and in particular if ART concentration is inadequate in tissues where viral reactivation is occurring [123]. "Block and lock" avoids these complications. Complete transcriptional silencing of the virus would also eliminate the low-level virus production that occurs during ART when virus is intermittently expressed in reservoir cells [124]. These small amounts of virus may drive low level chronic inflammation and immune activation. Even partial silencing could allow reduction in the effective size of the reservoir so that an engineered immune response might be able to keep the residual virus in check. Alternatively, "shock and kill" might be used to initially reduce the size of the reservoir, and then "block and lock" deployed to control the small residual reservoir, perhaps as an adjunct to an engineered immune response.

Mechanistically, "block and lock" could target either the viral or the host factors involved in HIV replication, transcription or translation (Figure 3). Although attractive due to reduced resistance, targeting of host proteins has the potential to affect multiple signaling pathways leading to unwanted and potentially unpredictable side effects. Virus-directed strategies could be aimed not only at the integrated proviral DNA but also at viral RNAs or even viral proteins. In recent years, various approaches have been proposed and tested, some in simplified and non-physiological model systems but others in vivo, including in human clinical studies. We will summarize the most promising approaches in the following sections. 


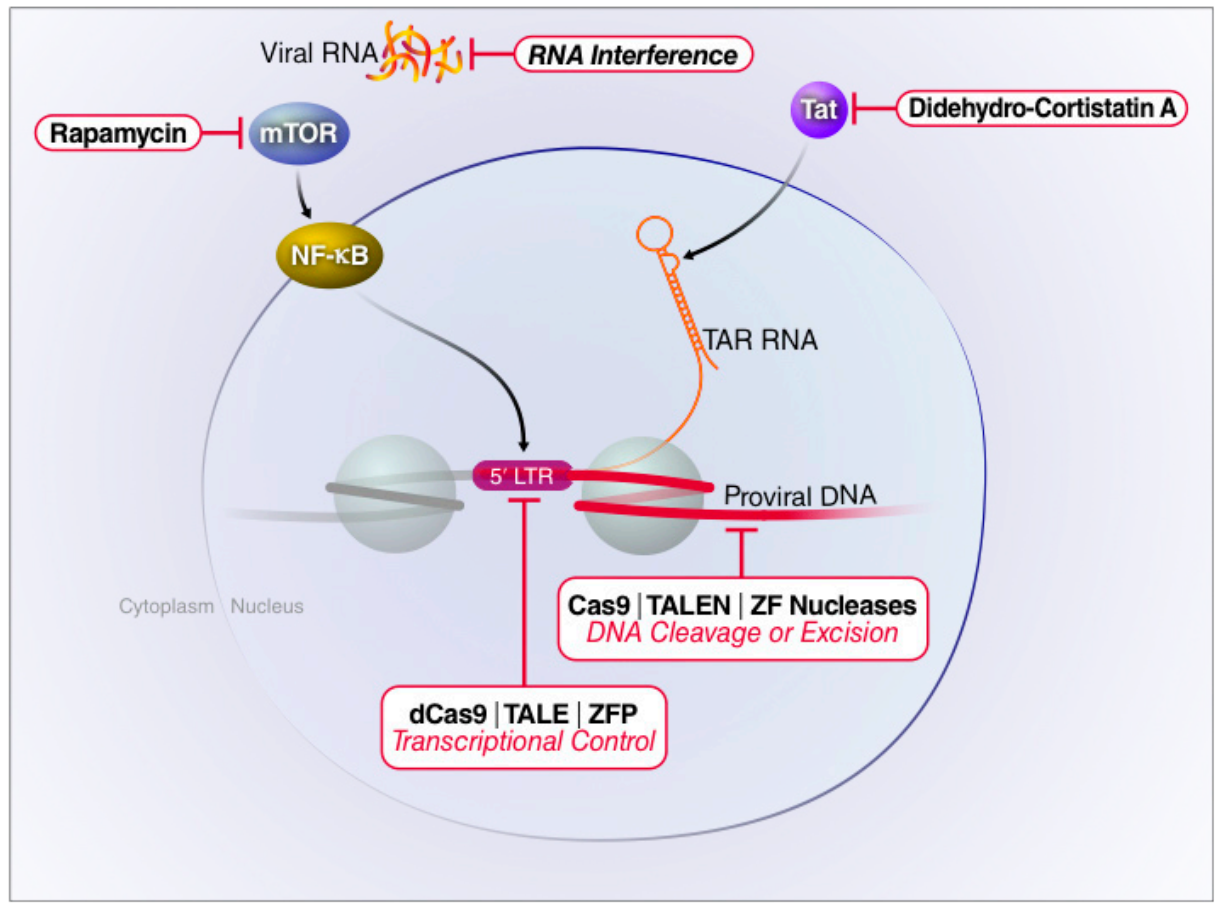

Figure 3. Targeting of host or viral factors to silence latent HIV proviruses. Therapeutics devised to inhibit HIV-1 replication may target different stages of the viral life cycle. The small molecule drug rapamycin blocks viral transcription initiation by inhibiting mTOR and AKT-mediated induction of NF- $\mathrm{B}$. Didehydro-cortistatin A interferes with Tat-mediated transactivation by blocking Tat binding to TAR, thereby reducing RNA Pol II elongation. RNA interference predominantly acts by degrading viral transcripts. Gene editing technologies directly target proviral DNA by either excising or corrupting the viral genome. CRISPR interference (CRISPRi) does not cleave the proviral DNA. Rather, a catalytically inactive Cas9 (dCas9) protein is fused to a Krüppel associated box (KRAB) domain and directed to the HIV-1 LTR by sgRNAs. This fusion protein recruits transcriptional repressors producing epigenetic changes associated with gene silencing.

\subsection{Pharmacologic Inhibition of Host Factors}

One example of a small-molecule drug qualifying as a "block and lock" or latency-promoting agent (LPA) is the macrolide rapamycin (sirolimus). Rapamycin is the eponymous inhibitor of the mammalian target of rapamycin (mTOR), a protein complex that controls a wide range of cellular activities including differentiation, viability and cell growth [125]. In the context of HIV, rapamycin downregulates surface expression of the CCR5 [126] and CXCR4 [127] co-receptors, thus inhibiting R5- and X4-tropic viral entry. Rapamycin also interferes with viral transcription [128] and latency reversal [129]. As of August 2019, two clinical trials with rapamycin have been conducted examining drug impact on HIV persistence and immune activation/inflammation. One study involved a combination of rapamycin with the CCR5 agonist Maraviroc (NCT02990312), while the second tested rapamycin alone (NCT02440789). Both studies are now complete, but results are not yet available. Of note, rapamycin alone is unlikely to allow the discontinuation of ART, but it could reduce viral transcriptional activity and reservoir size [130]. Rapamycin might also be used in combination with various LRAs to block LRA-mediated induction of a cytokine storm [131]. However, as for many other host-directed therapies, it is likely that the immunosuppressive effects of this drug will preclude its long-term use.

HIV transcription is critically dependent on the regulatory action of the viral trans-activator protein (Tat) [132]. The cellular cyclin-dependent kinase 9 (CDK9) is a key host factor that is required for Tat-dependent viral gene expression. CDK9 assembles with cyclin T1 to form the PTEF-b complex that binds to Tat and is recruited to HIV's TAR element by the RNA binding properties of Tat. PTEF-b phosphorylates the C-terminal domain of paused RNA Pol II polymerase complexes bound 
to the HIV proviral template, thus promoting transcriptional elongation by the complex [132]. Not surprisingly, inhibitors of CDK9 impair HIV-1 activation in both cell line models of HIV-1 latency and in infected peripheral blood lymphocytes analyzed in vitro [133-137]. The CDK9 antagonist, indirubin 3 '-monoxime, induces a sustained reduction of viremia in the absence of significant cytotoxicity or other severe adverse effects in a humanized mouse model of chronic HIV infection [138]. However, the ability of CDK9 to pair with different cyclins to affect RNA Pol II initiation, elongation, and termination predicts that long-term targeting of CDK9 will be associated with unacceptable adverse effects.

Vargas et al. [53] recently took a more unbiased approach in an attempt to identify antagonists of HIV-1 expression, screening a large library of clinically applicable kinase inhibitors in a cell line model of viral latency. As expected, this screen identified protein kinase $C$ inhibitors but surprisingly also danusertib, an Aurora kinase inhibitor, and PF-3758309, a PAK4 (p21-activated kinase 4) inhibitor, as agents that block latency reversal in cell lines as well as CD4+ T cells from HIV-1 infected individuals on long-term ART. The precise mechanism of action of these different kinase inhibitors remains unclear and again, overall enthusiasm for their use is tempered by the central role that these kinases play in cell mitosis, adhesion, migration, proliferation, and survival. Other previously identified latency-promoting agents include curaxin (CBL0100), a small molecule targeting the chromatin transcription complex (FACT) that efficiently blocks HIV-1 transcription in vitro and ex vivo [139]; levosimendan, which blocks viral replication through inhibition of the phosphoinositide 3-kinase pathway [140]; and ABX464, a drug that interacts with the Cap Binding Complex (CBC) and inhibits the Rev-dependent nuclear export of unspliced HIV transcripts [141]. ABX464 not only suppresses viral replication in vitro, but also delays viral rebound in humanized mice [141] and reduced viral reservoir size in early clinical studies $[139,142]$. Again however, the question remains whether the beneficial antiviral effects of these drugs outweigh the potentially harmful consequences of a long-lasting and systemic suppression of the respective cellular pathways.

Recently, lens-epithelium-derived growth factor p75 (LEDGF/p75) emerged as a key host determinant of HIV-1 latency, which, by controlling viral integration site selection [143,144], impacts the transcriptional activity of the provirus. LEDGINs, small molecules that block interactions between the viral integrase and LEDGF/p75 [145], retarget proviral integration to sites associated with a deeper state of latency [146]. Since LEDGINs also suppress viral spread by interfering with viral particle assembly [147], these agents could be used to both impair viral spread and, if such spread occurs, to promote latent proviruses that are more resistant to reactivation. However, previously established latent reservoirs are not predicted to be affected by LEDGINs, undermining their utility as curative agents [147].

\subsection{Small Molecule Inhibition of HIV Tat}

The HIV Tat protein is a major determinant of HIV replication and persistence, boosting viral gene expression by at least two orders of magnitude [148]. Weinberger and colleagues suggest that the rare stochastic loss of Tat expression drives the induction of latency, independent of the state of activation of the host cell [149-151]. As such, inhibition of Tat function might lead to marked silencing of the virus (reviewed in $[152,153]$ ).

Didehydro-cortistatin A (dCA) has been identified as a Tat inhibitor. dCA is an analogue of a steroidal alkaloid found in the marine sponge Corticium simplex. dCA binding to Tat impairs its interaction with TAR, thus interrupting Tat-mediated trans-activation [154]. Dr. Susana Valente and her colleagues have demonstrated that dCA efficiently disrupts the Tat-induced transcriptional feedback loop and establishes a long-term suppression of HIV transcription that persists even after removal of dCA. These long-lasting effects appear to involve heterochromatin formation within the HIV-1 LTR [155-157]. When tested in the BLT humanized mouse model, dCA significantly reduces viral mRNA levels in tissue reservoirs and delays viral rebound following treatment interruption [157]. Viral mutations conferring resistance to $\mathrm{dCA}$ have also been identified and are associated with heightened basal HIV-transcription leading to increased viral cytopathic effect and enhanced immune-mediated 
clearance [158]. It will be interesting to assess how long after drug removal the silencing effects of dCA persist, and whether this drug can be partnered with other agents to achieve synergistic silencing of latent HIV proviruses.

\subsection{Targeting HIV-1 mRNAs}

Since the advent of RNA interference (RNAi) in the 1990s (reviewed in $[159,160]$ ), this technology has rapidly expanded into the HIV field [161]. As compared to pharmacological approaches, RNAi has the intrinsic advantage of its sequence specificity. However, this same strength makes RNAi subject to viral evolution and emergence of resistance [162-164]. To circumvent viral evasion, multiple, highly conserved regions can be targeted where mutations result in a severe fitness cost [165-167]. In general, siRNAs work quite well in in vitro systems [161,167], but in vivo performance is often disappointing due to problems with delivery and the necessity for repeated administration to sustain effective siRNA levels (reviewed in $[165,168,169]$ ). Nevertheless, some success has been reported in humanized mouse models where interfering RNAs are delivered by lentiviruses, nanoparticles or dendrimers and aptamers (reviewed in [170]). Early human clinical trials have been limited, for ethical reasons, to HIV-1 infected individuals with concurrent cancers. DiGiusto and colleagues transduced hematopoietic stem and progenitor cells (HSPCs) ex vivo with RNA-based anti-HIV moieties and successfully engrafted these cells back into patients after radio- or chemotherapy [171]. Later studies utilized autologous hematopoietic cells, transduced with shRNA targeting CCR5 and the HIV-1 LTR. These cells were returned to the otherwise healthy HIV-1 infected donors (reviewed in [170]). However, in the initial trial, inconclusive results were obtained due to low in vivo frequencies of modified cells [171] while in the other case, the trial results remain pending (see [170] for trial identifier).

RNAi has often been proposed as a complement to current antiretroviral regimens. However, an often-underestimated aspect of RNAi-based approaches is its predilection to produce off-target effects [172], both sequence-specific and sequence-independent [173]. As such, long-term RNAi administration of siRNAs could be problematic.

\section{Gene Editing Strategies to Attack Latent HIV Proviruses}

All previously described "block and lock" approaches require at least minimal viral transcription and/or translation to be effective. However, recent studies suggest that viral reservoirs are mostly devoid of significant virus replication [174] and HIV gene expression [175,176]. Thus, most latently infected cells would not be affected by treatments targeting either viral transcripts or viral proteins, except during the narrow window of viral reactivation. Therapeutic targeting of the proviral DNA overcomes these limitations. A key prerequisite for this approach is a highly specific and easily adaptable DNA-binding moiety. In recent years, different DNA-binding proteins have been explored, including transcription activator-like effectors (TALEs), Zinc finger proteins (ZFPs), homing endonucleases (HEs), and clustered regularly interspaced palindromic repeats (CRISPR)-associated nucleases like Cas9 [177-179] (Figure 4). In their natural context, most DNA binding proteins also exert effector activities. For example, both HEs and Cas 9 cleave double stranded DNA, TALEs activate gene expression and ZFPs exert diverse functions including activation and inhibition of gene expression. For tailored applications, these proteins are often fused with specific effector protein domains including endonucleases, transcriptional activators, or transcriptional repressors. The transcriptional regulators act directly while the endonucleases act more indirectly by inducing double-strand breaks (DSBs) in their target sequences. Cellular mechanisms repair these DSBs, either via homology-directed repair/recombination (HDR) producing a clean, "scarless" repair, or, more frequently, via non-homologous end joining repair (NHEJ) that conversely generates a genetic scar characterized by insertions or deletions (indels). Indels within open reading frames have a two in three chance of producing frame-shift mutations that will disrupt natural viral protein production. In the following sections, we review how these gene editing approaches are being used to neutralize HIV. 


\section{Gene Editing Platforms}

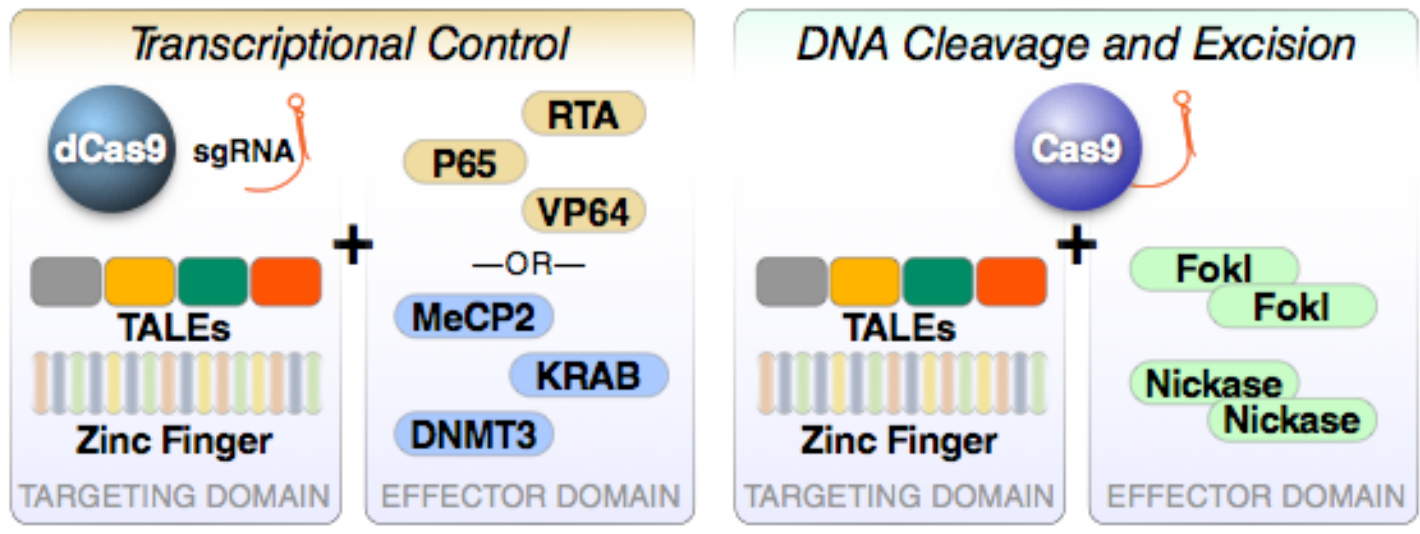

Figure 4. Major gene editing platforms operating through transcriptional control or DNA cleavage and excision. Two functions are present in all gene editing platforms. The first component directs sequence-specific DNA binding while the second promotes either frank DNA cleavage or the recruitment of epigenetic modifiers that positively or negatively control target gene transcription. For example, a catalytically inactive or dead version of Cas9 (dCas9) can be fused to a strong transcriptional activation domain from the RelA transcription factor (NF- $\mathrm{B}$ p65), the replication and transcription activator (RTA), or repeats of the HSV VP16 protein (VP64), to induce transcriptional activation. Alternatively, transcriptional inhibition can be induced by fusing dCas9 to Krueppel-associated box (KRAB) proteins, methyl CpG binding protein 2 (MeCP2), or DNA methyl transferase 3A (DNMT3a). These "baits" effectively recruit transcriptional repressors that silence gene activity via epigenetic mechanisms.

\subsection{Homing Endonucleases}

Homing endonucleases are naturally occurring DNA-cleaving enzymes that confer mobility to their own open reading frames [180]. They are highly specific for relatively long (12-40 bp) pre-defined DNA sequences, a property that unfortunately limits their utility. Only one report has appeared using HEs to target HIV. This study revealed only a modest reduction of viral gene expression in a cell line model of viral latency [172]. It seems quite unlikely that the HEs will gain traction as an effective anti-HIV therapeutic.

\subsection{Zinc Finger Proteins}

Zinc fingers are among the most abundant DNA-binding motifs in eukaryotes [181]. Natural zinc finger proteins (ZFPs) typically require at least three fingers to achieve sequence-specific binding [181]. Universal libraries and specific recognition codes are now available [182], enabling a modular assembly of sequence-specific ZFPs [183]. However, ZFP targets are limited by sequence requirements, and the engineering of these DNA-binding elements remains cumbersome and time-consuming [184]. A number of studies have utilized engineered ZFPs to target HIV proviruses. For example, ZFPs have been fused with nucleases [185-187] and transcriptional repressors [188-192] or activators [193], and tested in HIV-1 reporter cell lines and cell line models of HIV-1 latency, as well as primary human peripheral blood mononuclear cells $[185,188,190]$.

ZFPs have also been used to target the CCR5 co-receptor for HIV. This strategy seeks to phenocopy a naturally occurring homozygous deletion in the CCR5 gene (CCR5 $\Delta 32 / \Delta 32)$ known to confer high-level resistance to R5-tropic HIV-1 infection [194,195]. Mutation of this gene limited HIV-1 infection and spread in humanized mouse models [196,197]. CCR5-targeting ZFPs were also tested in a small-scale clinical study where autologous CD4 T cells from HIV-infected individual were edited ex vivo and reinfused. The CCR5-modified cells survived longer than the unmodified T cells, and plasma viral loads were lower during ART interruption [198]. Other clinical studies targeting CCR5 are currently recruiting or were recently completed but have not yet been reported (summarized in [199]). 
These studies generally support the feasibility of ZFP-based gene editing approaches to attack HIV via deletion of its key co-receptor. In contrast, targeting the latent HIV provirus for direct cleavage may be more difficult because these cells are rare and sequence variability may be encountered. In contrast, editing the CCR5 receptor in hematopoietic stem cells represents an exciting possibility for creating immune cells that are intrinsically resistant to HIV infection.

\subsection{TALES}

Transcription activator-like effectors (TALEs) are DNA binding proteins first identified in Xanthomonas bacteria infecting plants [194]. TALEs bind DNA via arrays of highly conserved 33-35 amino acid repeats. A single TALE repeat within an array binds specifically to individual DNA bases due to two hypervariable residues present at position 12 and 13 within the repeat [194]. The protein-DNA code of TALE repeats has been deciphered and enables the rapid and modular design of highly specific TALE-DNA binding proteins for virtually any given target sequence [200]. The majority of HIV-1 related studies have focused on transcription activator-like effectors nucleases (TALENs) - fusion proteins composed of specific TALE arrays and the FokI endonuclease (reviewed in [194]). In two separate studies, the introduction of TALENs targeting HIV proviral sequences within the LTR region in infected cell lines resulted in robust reduction of viral replication $[201,202]$ and the excision of proviral DNA [201].

TALENs are also showing promise in other strategies. Like ZFPs, TALENs have been used to knock out the CCR5 gene in cell culture [203-206], permitting efficient gene editing and protection of cells from HIV infection [207] with minimal off-target activity and low cytotoxicity. TALE-activators, corresponding to TALEs fused to potent transcription activators, have been developed and shown to effectively reactivate latent HIV-1 in cell line models [208-210] and in PBMCs from ART-suppressed individuals [210].

TALE technology combines several features that are quite favorable for gene editing applications. TALEs are specific, easy to design and generally less cytotoxic than other DNA targeting proteins [206]. On the downside, TALEs are relatively large and contain repetitive sequences that can complicate cloning [211] and interfere with incorporation into gene delivery vectors [212,213].

\subsection{CRISPR}

The recent discovery of clustered regularly interspaced short palindromic repeats or CRISPR has revolutionized gene editing in mammalian cells. CRISPR repetitive sequences were initially discovered in bacteria [214], where they form part of a larger protective response aimed at bacteriophages and other intrusive DNAs [215,216]. Bacterial helicases such as Cas9 bind CRISPR RNAs (crRNA), which then target pathogenic DNA leading to Cas9-mediated cleavage and degradation of the external threat [216]. The ability of CRISPR to direct double-strand DNA cleavage by Cas9 at specific sites through the action of crRNAs (or small guide RNAs, sgRNAs) has created an immensely powerful gene editing tool. CRISPR/Cas9 applications are also not limited to genome editing by DNA cleavage. The introduction of a mutation within the two nuclease domains, RuvC and $\mathrm{HNH}$, results in a catalytically inactive protein termed "dead" Cas9 (dCas9). dCas9 can be fused to an activator or conversely to a host protein that effectively recruits repressor complexes to achieve either gene activation or gene silencing [217]. One challenge with this approach is the fact that Cas9 and dCas9 are bacterial proteins and thus highly immunogenic [218]. This constraint will likely limit serial dosing of cocktails containing Cas9/dCas9.

CRISPR/Cas9 technology was first applied to HIV-1 in 2013 [219], with several rapidly ensuing studies (reviewed in [216]). Proviral cleavage by CRISPR was often tested in cell lines, like HEK 293T cells and HeLa [219-223], which unfortunately do not resemble natural targets of HIV. However, this technology was also shown to be effective in more relevant $T$ cell lines [219-223] and in cell line models of HIV-1 latency [220,222-224]. Importantly, CRISPR/Cas9 has now been used to successfully edit HIV-1 in in vitro-infected primary cells and in PBMCs from ART-suppressed individuals [225]. Multiple studies have also shown the successful application of CRISPR-Cas9 in HIV-1 infected 
humanized mice [226-229]. These developments culminated in an interesting humanized mouse study showing that the combination CRISPR/Cas9 and a long-acting slow-effective release ART (LASER ART) achieved apparently complete viral clearance in the absence of any detectable Cas9-mediated off-target effects [229].

One concern with CRISPR approaches directed against HIV-1 is that the double strand breaks and resulting mutations, while crippling the majority of the edited viruses, may in some cases facilitate viral escape [230-233]: some of the NHEJ-induced random mutations may be silent and not reduce viral fitness. Such mutant viruses would no longer be susceptible to further CRISPR suppression and could rapidly repopulate the target cell pool [230-232]. In vitro, multiplexing with several guide sequences and targeting multiple highly conserved viral regions could minimize this problem [224,234]. A larger issue is the frequency of off-target editing by the CRISPR/Cas9 system [235,236].

Several prior studies have also focused on knocking out the HIV co-receptors, CCR5 and CXCR4, as a means to block viral spread. As expected, CRISPR-Cas9-mediated knockout of the CCR5 gene inhibited HIV-1 infection in induced pluripotent stem cell-derived monocyte/macrophages [237], primary CD4+ T cells [238], and in vivo [239,240]. Similarly, CXCR4 knockout was shown to confer resistance to X4-tropic virus infection [241-243]. However, in view of the importance of CXCR4 in the development of hematopoietic cells [244], the clinical feasibility of this latter knockout approach is more problematic.

A number of CRISPR-based approaches have made use of the catalytically inactive dCas9 mutant. Fused with a potent transcriptional activator, dCas9 enables specific induction of gene expression, an approach termed CRISPR activation (CRISPRa) [217]. This approach supports strong in vitro re-activation of latent HIV-1 [245-251] at levels greater than most tested latency-reversing agents [246]. In some cases, viral burst size is increased sufficiently to induce viral cytopathic effects [250]. CRISPRa has been successfully tested in cell lines and cell line models of latency [245-251], but not yet in primary cells or in vivo. CRISPRa could also be used to upregulate protective, antiviral factors in order to control HIV-1 infections. In early proof-of-concept studies, CRISPRa has been shown to activate the expression of the HIV-1 restriction factors APOBEC3 [252] and BST-2/Tetherin [253] and to inhibit HIV-1 infectivity.

Conversely, catalytically inactive or "dead" Cas9 (dCas9) can be used to suppress viral transcription via CRISPR interference, or CRISPRi [246]. A preliminary study suggests that suppression can be significantly improved by fusing dCas9 to the Krueppel-associated box domain (KRAB) that in turn recruits other repressor complexes [221]. More focused studies are necessary to thoroughly explore the efficacy and applicability of the CRISRPi/CRISPRa modalities in HIV-1 cure approaches. Drawbacks of this approach include issues of sustained gene delivery and the intrinsic immunogenicity of the bacterial Cas9 protein.

\subsection{Summary and Conclusions}

Each of the described gene editing approaches exhibits advantages and disadvantages. Strengths and weaknesses vary depending on the target cell population and the editing context. For example, the problematic immunogenicity of the bacterial Cas9 protein that occurs in vivo is of less concern when "hit and run editing" is performed ex vivo and modified cells then reinfused. The size of the editing components also varies (CRISPR $>4000$ base pairs vs. ZFP $<1000$ base pairs), which can limit the use of select transfer vectors. A summary of all of the genome editing tools discussed in this review is provided in Table 1. Importantly, only a few studies have performed actual side-by-side comparisons of these different editing systems. The purpose of the table is to provide a global overview of the features of HE, ZFP, TALE and CRISPR platforms based on published reports and reviews. 
Table 1. Properties of common gene editing platforms.

\begin{tabular}{|c|c|c|c|c|}
\hline & HE & ZFP & TALE & CRISPR \\
\hline $\begin{array}{l}\text { Target sequence } \\
\text { constraints }\end{array}$ & $\begin{array}{l}\text { High (pre-defined } \\
\text { targets) }\end{array}$ & $\begin{array}{c}\text { No constraints (any } \\
\text { sequence) }\end{array}$ & $\begin{array}{c}\text { No constraints (any } \\
\text { sequence) }\end{array}$ & Low (PAM required) \\
\hline $\begin{array}{c}\text { Design and assembly } \\
{[213]}\end{array}$ & Difficult & Moderate & Easy & Very easy \\
\hline Toxicity $[206,211,255]$ & Low & High & Low & $\begin{array}{c}\text { Unclear, high in some } \\
\text { cell lineages }\end{array}$ \\
\hline $\begin{array}{c}\text { Specificity } \\
{[211,254,256,257]}\end{array}$ & High & Low to Moderate & Moderate to High & Low to Moderate \\
\hline $\begin{array}{c}\text { Multiplexing } \\
\text { suitability [254] }\end{array}$ & Low & Low & Moderate & High \\
\hline Source [254] & $\begin{array}{c}\text { Organelles, Bacteria, } \\
\text { Phages }\end{array}$ & Bacteria, Eukaryotes & Bacteria & Bacteria \\
\hline $\begin{array}{c}\text { Immunogenicity } \\
{[218,254]}\end{array}$ & Unknown & Low & Unknown & $\begin{array}{c}\text { Prevalent pre-existing } \\
\text { immunity }\end{array}$ \\
\hline $\begin{array}{l}\text { Size of effector protein } \\
\text { in kDa }[258,259]\end{array}$ & $<40$ & $\sim 40$ & $\sim 105$ & $\sim 160$ \\
\hline $\begin{array}{c}\text { Average length of } \\
\text { effector protein } \\
{[258,260]}\end{array}$ & $200-300$ aa & $120-180$ aа & $660-700$ aа & 1400 aa \\
\hline $\begin{array}{l}\text { Sensitivity to chromatin } \\
\text { condensation }[261,262]\end{array}$ & $\begin{array}{l}\text { Sensitive to chromatin } \\
\text { compactation and CpG } \\
\text { Methylation }\end{array}$ & $\begin{array}{c}\text { Binds condensed and } \\
\text { hypermethylated DNA }\end{array}$ & $\begin{array}{l}\text { Potentially decreased } \\
\text { binding of condensed } \\
\text { DNA }\end{array}$ & $\begin{array}{c}\text { Targeting of } \\
\text { hypermethylated } \mathrm{CpG} \\
\text { islands may be limited }\end{array}$ \\
\hline
\end{tabular}

\subsection{Challenges}

The majority of the anti-HIV gene therapy approaches directly attack either the virus itself or host genes that are critical for viral growth and spread. As described above, nuclease-based strategies result in double strand breaks (DSBs), which are predominantly repaired by error-prone non-homologous end joining. However, DSBs can also produce toxic effects [263], potentially promoting neoplastic transformation or other life-threatening disorders [264]. In the case of HIV-infected individuals who are doing well on ART, therapeutic approaches involving the introduction of DSBs may be judged too risky. Conversely, the use of inactive Cas9 fused to transcriptional activators or inhibitors could be deployed with less toxicity, but the intrinsic immunogenicity of the bacterial Cas9 protein complicates repeated use. Other major issues relate to gene delivery and sustained expression of the gene cargo. In the case of HIV, the ultimate approaches must be safe, effective and scalable, including deployment within the developing world where HIV is hitting the hardest.

\section{Concluding Thoughts}

Simply put, the HIV cure field has entered a period of considerable uncertainty. Initial enthusiasm for "shock and kill" as a cure strategy has receded chiefly because safe and effective LRAs have been difficult to identify. Disturbingly, many of the most promising shocking agents actually undermine CTL effector function. Further, in vitro activations studies revealed that only a small percentage of the replication-competent HIV reservoir is activated with strong LRAs $[8,68,117]$. As such, multiple rounds of LRA treatment will be required and the toxicity profile of these agents is critical. Clearly, the majority of the current LRAs are not up to the task, and further basic research is necessary to better understand why previous cure approaches failed and how future attempts may overcome existing roadblocks.

Ultimately, if sufficient latency reversal is achieved in vivo, a variety of killing mechanisms could be deployed. It is unclear what immune interventions will be the most successful but bNAbs, therapeutic vaccines, NK cells coupled with bNAbs for ADCC, CTLs, and even engineered killer cells should be further explored (Figure 5). These agents could be used to both initially reduce the size of the reservoir and then control the small residual pool of viruses. 


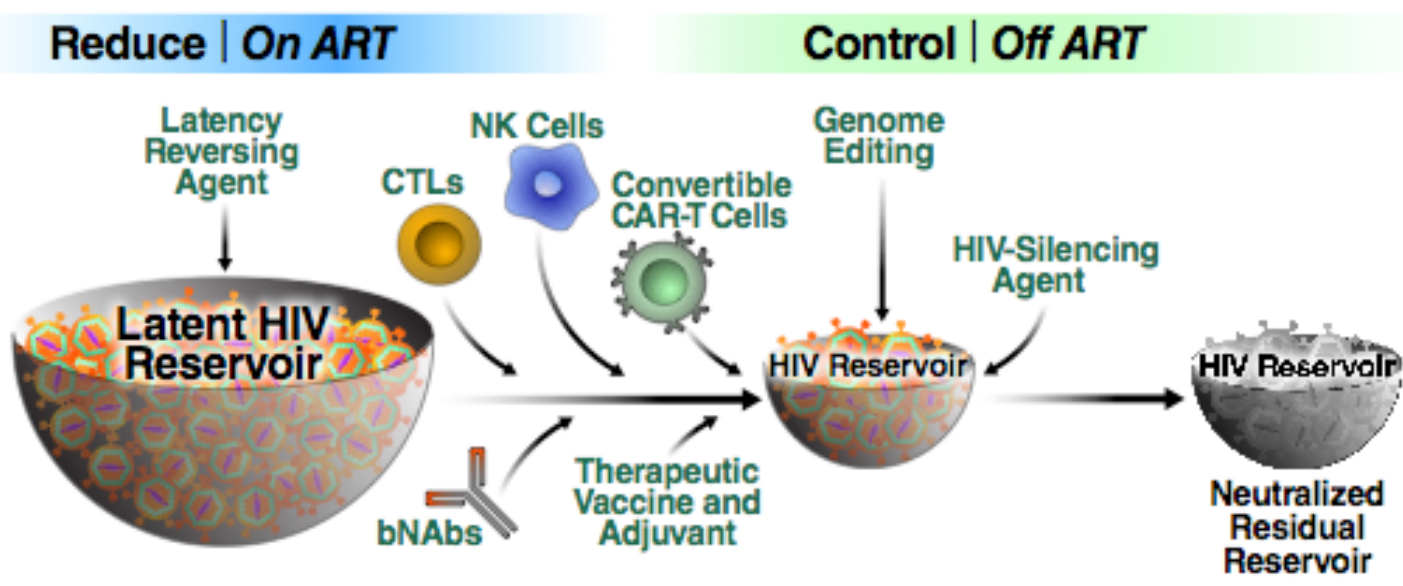

Figure 5. Schematic representation of the "reduce and control" approach. First, a combination of effective, non-toxic LRAs are employed in order to render reservoir cells visible to the immune system. The reservoir is then reduced in size likely through the use of multiple agents including bNAbs, various killer cells and therapeutic vaccines. The residual virus can be controlled by the same agents used to reduce the size of the reservoir. However, this shrunken reservoir could form an attractive target for additional transcriptional silencing approaches. We believe it likely that some form of this combinatorial "reduce and control" strategy will emerge as a means of achieving a sustained HIV remission in the absence of ART.

Within this review, we have not addressed pharmacological killing agents that augment elimination of virus-infected cells, which have been the subject of a recent review by Kim et al. [115]. Potentially, one or more of these killing compounds may be included in "shock and kill" cocktails. At the moment, the SMAC mimetics, which both reverse latency and promote the death of reactivated reservoir cells, are the most interesting LRAs and merit careful examination in vivo. Analytical treatment interrupt (ATI) trials remain the only definitive way to assess if cure therapies lead to a sustained ART-free remission. In a recent study by Clarridge et al. [265], it was shown that ATI did not significantly increase the size of the reservoir, nor did it inflict permanent damage to the immune system. Although cumbersome, ATI is likely to remain the gold standard for definitive testing of promising cure interventions.

In our opinion, "shock and kill" as a stand-alone approach to an HIV cure is unlikely to be effective. In fact, in view of the stochastic nature of latency reversal [8] and the fractional induction of virus observed, a more robust approach than offered by "shock and kill" is needed. Analogous to the success of combination antiretroviral therapy attacking different steps in the HIV life cycle, we believe a combinatorial approach will be required to neutralize the viral reservoir. We predict the first cures will not involve complete viral eradication but rather "functional cures" where the size of the reservoir is reduced and the residual virus controlled by an engineered immune intervention as described above. We further suggest that "block and lock" or transcriptional silencing approaches will likely play an important role in the control of residual viremia after the reservoir has been reduced in size. In this context, the emergence of Tat inhibitors like didehydro-cortistatin A, which exhibit virus specificity and sustained viral suppression even after drug withdrawal, is intriguing and certainly worthy of detailed investigation. The sequence-specific nature of gene editing platforms is also attractive for attacking HIV. The flexibility and modularity of the RNA guided CRISPR system is an undeniable advantage that seems to outweigh some of its inherent shortcomings. However, safety concerns have to be thoroughly addressed before gene therapies can be administered widely to HIV-infected individuals, especially individuals who are doing well on ART. An absolute key will be getting a "lock" into "block and lock" that allows for permanent silencing of HIV proviruses in the absence of continuous drug treatment. Simply replacing ART with another set of long-term drugs would not be a desirable outcome. On a global scale, an ability to reproducibly achieve a sustained remission of HIV in the absence of ART in 
resource-limited environments would not only save billions of dollars annually spent on daily ART, but would also transform sub-Saharan's Africa's ability to end it longstanding struggle against HIV/AIDS.

Author Contributions: Conceptualization, W.C.G., A.G. and R.S.; writing-original draft preparation, R.S., A.G., W.C.G.; writing-review and editing, W.C.G.; visualization, W.C.G., A.G., R.S. All authors have read and agreed to the published version of the manuscript.

Funding: The authors acknowledge the following sources of funding: R01DA044605 (WCG), P01 AI131374 (WCG), R01DA049525-01 (WCG), P01 10018714-701(WCG), amfAR Institute for HIV Cure Research (WCG, RS, AG), UCSF-Gladstone Center for AIDS Research (P30 AI027763) (RS), the James B. Pendleton Charitable Trust, and the J. David Gladstone Institutes.

Acknowledgments: The authors thank Robin Givens for administrative assistance, John C.W. Carroll for graphic arts, and Françoise Chanut for editorial assistance.

Conflicts of Interest: The authors declare no conflicts of interest.

\section{References}

1. Greene, W.C. A history of AIDS: Looking back to see ahead. Eur. J. Immunol. 2007, 37 (Suppl. 1), S94-S102. [CrossRef]

2. Barre-Sinoussi, F.; Chermann, J.C.; Rey, F.; Nugeyre, M.T.; Chamaret, S.; Gruest, J.; Dauguet, C.; Axler-Blin, C.; Vezinet-Brun, F.; Rouzioux, C.; et al. Isolation of a T-lymphotropic retrovirus from a patient at risk for acquired immune deficiency syndrome (AIDS). Science 1983, 220, 868-871. [CrossRef]

3. Gallo, R.C.; Salahuddin, S.Z.; Popovic, M.; Shearer, G.M.; Kaplan, M.; Haynes, B.F.; Palker, T.J.; Redfield, R.; Oleske, J.; Safai, B.; et al. Frequent detection and isolation of cytopathic retroviruses (HTLV-III) from patients with AIDS and at risk for AIDS. Science 1984, 224, 500-503. [CrossRef]

4. Popovic, M.; Sarngadharan, M.G.; Read, E.; Gallo, R.C. Detection, isolation, and continuous production of cytopathic retroviruses (HTLV-III) from patients with AIDS and pre-AIDS. Science 1984, 224, 497-500. [CrossRef] [PubMed]

5. Schupbach, J.; Popovic, M.; Gilden, R.V.; Gonda, M.A.; Sarngadharan, M.G.; Gallo, R.C. Serological analysis of a subgroup of human T-lymphotropic retroviruses (HTLV-III) associated with AIDS. Science 1984, 224, 503-505. [CrossRef] [PubMed]

6. Bruner, K.M.; Murray, A.J.; Pollack, R.A.; Soliman, M.G.; Laskey, S.B.; Capoferri, A.A.; Lai, J.; Strain, M.C.; Lada, S.M.; Hoh, R.; et al. Defective proviruses rapidly accumulate during acute HIV-1 infection. Nat. Med. 2016, 22, 1043-1049. [CrossRef] [PubMed]

7. Pollack, R.A.; Jones, R.B.; Pertea, M.; Bruner, K.M.; Martin, A.R.; Thomas, A.S.; Capoferri, A.A.; Beg, S.A.; Huang, S.H.; Karandish, S.; et al. Defective HIV-1 Proviruses Are Expressed and Can Be Recognized by Cytotoxic T Lymphocytes, which Shape the Proviral Landscape. Cell Host Microbe 2017, 21, 494-506.e494. [CrossRef]

8. Ho, Y.C.; Shan, L.; Hosmane, N.N.; Wang, J.; Laskey, S.B.; Rosenbloom, D.I.; Lai, J.; Blankson, J.N.; Siliciano, J.D.; Siliciano, R.F. Replication-competent noninduced proviruses in the latent reservoir increase barrier to HIV-1 cure. Cell 2013, 155, 540-551. [CrossRef]

9. DeMaster, L.K.; Liu, X.; VanBelzen, D.J.; Trinite, B.; Zheng, L.; Agosto, L.M.; Migueles, S.A.; Connors, M.; Sambucetti, L.; Levy, D.N.; et al. A Subset of CD4/CD8 Double-Negative T Cells Expresses HIV Proteins in Patients on Antiretroviral Therapy. J. Virol. 2015, 90, 2165-2179. [CrossRef]

10. Imamichi, H.; Dewar, R.L.; Adelsberger, J.W.; Rehm, C.A.; O’Doherty, U.; Paxinos, E.E.; Fauci, A.S.; Lane, H.C. Defective HIV-1 proviruses produce novel protein-coding RNA species in HIV-infected patients on combination antiretroviral therapy. Proc. Natl. Acad. Sci. USA 2016, 113, 8783-8788. [CrossRef]

11. Deeks, S.G.; Tracy, R.; Douek, D.C. Systemic effects of inflammation on health during chronic HIV infection. Immunity 2013, 39, 633-645. [CrossRef]

12. Bruel, T.; Schwartz, O. Markers of the HIV-1 reservoir: Facts and controversies. Curr. Opin. HIV AIDS 2018, 13, 383-388. [CrossRef] [PubMed]

13. Tabler, C.O.; Lucera, M.B.; Haqqani, A.A.; McDonald, D.J.; Migueles, S.A.; Connors, M.; Tilton, J.C. CD4+ memory stem cells are infected by HIV-1 in a manner regulated in part by SAMHD1 expression. J. Virol. 2014, 88, 4976-4986. [CrossRef] 
14. Zaikos, T.D.; Terry, V.H.; Sebastian Kettinger, N.T.; Lubow, J.; Painter, M.M.; Virgilio, M.C.; Neevel, A.; Taschuk, F.; Onafuwa-Nuga, A.; McNamara, L.A.; et al. Hematopoietic Stem and Progenitor Cells Are a Distinct HIV Reservoir that Contributes to Persistent Viremia in Suppressed Patients. Cell Rep. 2018, 25, 3759-3773.e3759. [CrossRef] [PubMed]

15. Aid, M.; Dupuy, F.P.; Moysi, E.; Moir, S.; Haddad, E.K.; Estes, J.D.; Sekaly, R.P.; Petrovas, C.; Ribeiro, S.P. Follicular CD4 T Helper Cells As a Major HIV Reservoir Compartment: A Molecular Perspective. Front. Immunol. 2018, 9, 895. [CrossRef]

16. Bronnimann, M.P.; Skinner, P.J.; Connick, E. The B-Cell Follicle in HIV Infection: Barrier to a Cure. Front. Immunol. 2018, 9, 20. [CrossRef] [PubMed]

17. Fukazawa, Y.; Lum, R.; Okoye, A.A.; Park, H.; Matsuda, K.; Bae, J.Y.; Hagen, S.I.; Shoemaker, R.; Deleage, C.; Lucero, C.; et al. B cell follicle sanctuary permits persistent productive simian immunodeficiency virus infection in elite controllers. Nat. Med. 2015, 21, 132-139. [CrossRef] [PubMed]

18. Bozzi, G.; Simonetti, F.R.; Watters, S.A.; Anderson, E.M.; Gouzoulis, M.; Kearney, M.F.; Rote, P.; Lange, C.; Shao, W.; Gorelick, R.; et al. No evidence of ongoing HIV replication or compartmentalization in tissues during combination antiretroviral therapy: Implications for HIV eradication. Sci. Adv. 2019, 5, eaav2045. [CrossRef]

19. Chaillon, A.; Gianella, S.; Dellicour, S.; Rawlings, S.A.; Schlub, T.E.; Faria De Oliveira, M.; Ignacio, C.; Porrachia, M.; Vrancken, B.; Smith, D.M. HIV persists throughout deep tissues with repopulation from multiple anatomical sources. J. Clin. Investig. 2020. [CrossRef]

20. Prevedel, L.; Ruel, N.; Castellano, P.; Smith, C.; Malik, S.; Villeux, C.; Bomsel, M.; Morgello, S.; Eugenin, E.A. Identification, Localization, and Quantification of HIV Reservoirs Using Microscopy. Curr. Protoc. Cell Biol. 2019, 82, e64. [CrossRef]

21. Henrich, T.J.; Deeks, S.G.; Pillai, S.K. Measuring the Size of the Latent Human Immunodeficiency Virus Reservoir: The Present and Future of Evaluating Eradication Strategies. J. Infect. Dis. 2017, 215, S134-S141. [CrossRef] [PubMed]

22. Prakash, K.; Gianella, S.; Dube, K.; Taylor, J.; Lee, G.; Smith, D.M. Willingness to participate in HIV research at the end of life (EOL). PLoS ONE 2018, 13, e0199670. [CrossRef] [PubMed]

23. Kulpa, D.A.; Talla, A.; Brehm, J.H.; Ribeiro, S.P.; Yuan, S.; Bebin-Blackwell, A.G.; Miller, M.; Barnard, R.; Deeks, S.G.; Hazuda, D.; et al. Differentiation into an Effector Memory Phenotype Potentiates HIV-1 Latency Reversal in CD4(+) T Cells. J. Virol. 2019, 93. [CrossRef] [PubMed]

24. Bisgrove, D.; Lewinski, M.; Bushman, F.; Verdin, E. Molecular mechanisms of HIV-1 proviral latency. Expert. Rev. Anti Infect. Ther. 2005, 3, 805-814. [CrossRef] [PubMed]

25. Cesana, D.; Santoni de Sio, F.R.; Rudilosso, L.; Gallina, P.; Calabria, A.; Beretta, S.; Merelli, I.; Bruzzesi, E.; Passerini, L.; Nozza, S.; et al. HIV-1-mediated insertional activation of STAT5B and BACH2 trigger viral reservoir in T regulatory cells. Nat. Commun. 2017, 8, 498. [CrossRef]

26. Cohn, L.B.; Silva, I.T.; Oliveira, T.Y.; Rosales, R.A.; Parrish, E.H.; Learn, G.H.; Hahn, B.H.; Czartoski, J.L.; McElrath, M.J.; Lehmann, C.; et al. HIV-1 integration landscape during latent and active infection. Cell 2015, 160, 420-432. [CrossRef]

27. Hughes, S.H.; Coffin, J.M. What Integration Sites Tell Us about HIV Persistence. Cell Host Microbe 2016, 19, 588-598. [CrossRef]

28. Maldarelli, F.; Wu, X.; Su, L.; Simonetti, F.R.; Shao, W.; Hill, S.; Spindler, J.; Ferris, A.L.; Mellors, J.W.; Kearney, M.F.; et al. HIV latency. Specific HIV integration sites are linked to clonal expansion and persistence of infected cells. Science 2014, 345, 179-183. [CrossRef]

29. Symons, J.; Cameron, P.U.; Lewin, S.R. HIV integration sites and implications for maintenance of the reservoir. Curr. Opin. HIV AIDS 2018, 13, 152-159. [CrossRef]

30. Wagner, T.A.; McLaughlin, S.; Garg, K.; Cheung, C.Y.; Larsen, B.B.; Styrchak, S.; Huang, H.C.; Edlefsen, P.T.; Mullins, J.I.; Frenkel, L.M. HIV latency. Proliferation of cells with HIV integrated into cancer genes contributes to persistent infection. Science 2014, 345, 570-573. [CrossRef]

31. Ruelas, D.S.; Greene, W.C. An integrated overview of HIV-1 latency. Cell 2013, 155, 519-529. [CrossRef] [PubMed]

32. He, G.; Margolis, D.M. Counterregulation of chromatin deacetylation and histone deacetylase occupancy at the integrated promoter of human immunodeficiency virus type 1 (HIV-1) by the HIV-1 repressor YY1 and HIV-1 activator Tat. Mol. Cell Biol. 2002, 22, 2965-2973. [CrossRef] [PubMed] 
33. Khan, S.; Iqbal, M.; Tariq, M.; Baig, S.M.; Abbas, W. Epigenetic regulation of HIV-1 latency: Focus on polycomb group (PcG) proteins. Clin. Epigenetics 2018, 10, 14. [CrossRef]

34. Nguyen, K.; Das, B.; Dobrowolski, C.; Karn, J. Multiple Histone Lysine Methyltransferases Are Required for the Establishment and Maintenance of HIV-1 Latency. MBio 2017, 8. [CrossRef] [PubMed]

35. Tacheny, A.; Michel, S.; Dieu, M.; Payen, L.; Arnould, T.; Renard, P. Unbiased proteomic analysis of proteins interacting with the HIV-1 5'LTR sequence: Role of the transcription factor Meis. Nucleic Acids Res. 2012, 40, e168. [CrossRef] [PubMed]

36. Dlamini, Z.; Hull, R. Can the HIV-1 splicing machinery be targeted for drug discovery? HIV AIDS (Auckl.) 2017, 9, 63-75. [CrossRef] [PubMed]

37. Charnay, N.; Ivanyi-Nagy, R.; Soto-Rifo, R.; Ohlmann, T.; Lopez-Lastra, M.; Darlix, J.L. Mechanism of HIV-1 Tat RNA translation and its activation by the Tat protein. Retrovirology 2009, 6, 74. [CrossRef]

38. Zapata, J.C.; Campilongo, F.; Barclay, R.A.; DeMarino, C.; Iglesias-Ussel, M.D.; Kashanchi, F.; Romerio, F. The Human Immunodeficiency Virus 1 ASP RNA promotes viral latency by recruiting the Polycomb Repressor Complex 2 and promoting nucleosome assembly. Virology 2017, 506, 34-44. [CrossRef]

39. Maenza, J.; Tapia, K.; Holte, S.; Stekler, J.D.; Stevens, C.E.; Mullins, J.I.; Collier, A.C. How often does treatment of primary HIV lead to post-treatment control? Antivir. Ther. 2015, 20, 855-863. [CrossRef]

40. Namazi, G.; Fajnzylber, J.M.; Aga, E.; Bosch, R.J.; Acosta, E.P.; Sharaf, R.; Hartogensis, W.; Jacobson, J.M.; Connick, E.; Volberding, P.; et al. The Control of HIV After Antiretroviral Medication Pause (CHAMP) Study: Posttreatment Controllers Identified From 14 Clinical Studies. J. Infect. Dis. 2018, 218, 1954-1963. [CrossRef]

41. Etemad, B.; Esmaeilzadeh, E.; Li, J.Z. Learning From the Exceptions: HIV Remission in Post-treatment Controllers. Front. Immunol. 2019, 10, 1749. [CrossRef] [PubMed]

42. Goulder, P.; Deeks, S.G. HIV control: Is getting there the same as staying there? PLoS Pathog. 2018, 14, e1007222. [CrossRef] [PubMed]

43. Saez-Cirion, A.; Bacchus, C.; Hocqueloux, L.; Avettand-Fenoel, V.; Girault, I.; Lecuroux, C.; Potard, V.; Versmisse, P.; Melard, A.; Prazuck, T.; et al. Post-treatment HIV-1 controllers with a long-term virological remission after the interruption of early initiated antiretroviral therapy ANRS VISCONTI Study. PLoS Pathog. 2013, 9, e1003211. [CrossRef] [PubMed]

44. Sharaf, R.; Lee, G.Q.; Sun, X.; Etemad, B.; Aboukhater, L.M.; Hu, Z.; Brumme, Z.L.; Aga, E.; Bosch, R.J.; Wen, Y.; et al. HIV-1 proviral landscapes distinguish posttreatment controllers from noncontrollers. J. Clin. Investig. 2018, 128, 4074-4085. [CrossRef]

45. Wen, Y.; Li, J.Z. Post-treatment HIV controllers or spontaneous controllers in disguise? AIDS 2017, 31, 587-589. [CrossRef]

46. Pohlmeyer, C.W.; Gonzalez, V.D.; Irrinki, A.; Ramirez, R.N.; Li, L.; Mulato, A.; Murry, J.P.; Arvey, A.; Hoh, R.; Deeks, S.G.; et al. Identification of NK Cell Subpopulations That Differentiate HIV-Infected Subject Cohorts with Diverse Levels of Virus Control. J. Virol. 2019, 93. [CrossRef]

47. Henrich, T.J.; Hatano, H.; Bacon, O.; Hogan, L.E.; Rutishauser, R.; Hill, A.; Kearney, M.F.; Anderson, E.M.; Buchbinder, S.P.; Cohen, S.E.; et al. HIV-1 persistence following extremely early initiation of antiretroviral therapy (ART) during acute HIV-1 infection: An observational study. PLoS Med. 2017, 14, e1002417. [CrossRef]

48. Colby, D.J.; Trautmann, L.; Pinyakorn, S.; Leyre, L.; Pagliuzza, A.; Kroon, E.; Rolland, M.; Takata, H.; Buranapraditkun, S.; Intasan, J.; et al. Rapid HIV RNA rebound after antiretroviral treatment interruption in persons durably suppressed in Fiebig I acute HIV infection. Nat. Med. 2018, 24, 923-926. [CrossRef]

49. Whitney, J.B.; Hill, A.L.; Sanisetty, S.; Penaloza-MacMaster, P.; Liu, J.; Shetty, M.; Parenteau, L.; Cabral, C.; Shields, J.; Blackmore, S.; et al. Rapid seeding of the viral reservoir prior to SIV viraemia in rhesus monkeys. Nature 2014, 512, 74-77. [CrossRef]

50. Chomont, N.; El-Far, M.; Ancuta, P.; Trautmann, L.; Procopio, F.A.; Yassine-Diab, B.; Boucher, G.; Boulassel, M.R.; Ghattas, G.; Brenchley, J.M.; et al. HIV reservoir size and persistence are driven by T cell survival and homeostatic proliferation. Nat. Med. 2009, 15, 893-900. [CrossRef]

51. Siliciano, J.D.; Kajdas, J.; Finzi, D.; Quinn, T.C.; Chadwick, K.; Margolick, J.B.; Kovacs, C.; Gange, S.J.; Siliciano, R.F. Long-term follow-up studies confirm the stability of the latent reservoir for HIV-1 in resting CD4+ T cells. Nat. Med. 2003, 9, 727-728. [CrossRef] [PubMed]

52. Deeks, S.G. HIV: Shock and kill. Nature 2012, 487, 439-440. [CrossRef] [PubMed] 
53. Vargas, B.; Giacobbi, N.S.; Sanyal, A.; Venkatachari, N.J.; Han, F.; Gupta, P.; Sluis-Cremer, N. Inhibitors of Signaling Pathways That Block Reversal of HIV-1 Latency. Antimicrob. Agents Chemother. 2019, 63. [CrossRef] [PubMed]

54. Stephenson, K.E. Therapeutic vaccination for HIV: Hopes and challenges. Curr. Opin. HIV AIDS 2018, 13, 408-415. [CrossRef] [PubMed]

55. Fennessey, C.M.; Pinkevych, M.; Immonen, T.T.; Reynaldi, A.; Venturi, V.; Nadella, P.; Reid, C.; Newman, L.; Lipkey, L.; Oswald, K.; et al. Genetically-barcoded SIV facilitates enumeration of rebound variants and estimation of reactivation rates in nonhuman primates following interruption of suppressive antiretroviral therapy. PLoS Pathog. 2017, 13, e1006359. [CrossRef] [PubMed]

56. Mylvaganam, G.H.; Chea, L.S.; Tharp, G.K.; Hicks, S.; Velu, V.; Iyer, S.S.; Deleage, C.; Estes, J.D.; Bosinger, S.E.; Freeman, G.J.; et al. Combination anti-PD-1 and antiretroviral therapy provides therapeutic benefit against SIV. JCI Insight. 2018, 3. [CrossRef]

57. Goswami, R.; Nelson, A.N.; Tu, J.J.; Dennis, M.; Feng, L.; Kumar, A.; Mangold, J.; Mangan, R.J.; Mattingly, C.; Curtis, A.D., 2nd; et al. Analytical Treatment Interruption after Short-Term Antiretroviral Therapy in a Postnatally Simian-Human Immunodeficiency Virus-Infected Infant Rhesus Macaque Model. MBio 2019, 10. [CrossRef]

58. Caskey, M. Delivery of anti-HIV bNAbs by viral vectors. Lancet HIV 2019, 6, e207-e208. [CrossRef]

59. Blazkova, J.; Refsland, E.W.; Clarridge, K.E.; Shi, V.; Justement, J.S.; Huiting, E.D.; Gittens, K.R.; Chen, X.; Schmidt, S.D.; Liu, C.; et al. Glycan-dependent HIV-specific neutralizing antibodies bind to cells of uninfected individuals. J. Clin. Investig. 2019, 129, 4832-4837. [CrossRef]

60. Bruel, T.; Guivel-Benhassine, F.; Amraoui, S.; Malbec, M.; Richard, L.; Bourdic, K.; Donahue, D.A.; Lorin, V.; Casartelli, N.; Noel, N.; et al. Elimination of HIV-1-infected cells by broadly neutralizing antibodies. Nat. Commun. 2016, 7, 10844. [CrossRef]

61. Kim, J.H.; Excler, J.L.; Michael, N.L. Lessons from the RV144 Thai phase III HIV-1 vaccine trial and the search for correlates of protection. Annu. Rev. Med. 2015, 66, 423-437. [CrossRef]

62. Nishimura, Y.; Gautam, R.; Chun, T.W.; Sadjadpour, R.; Foulds, K.E.; Shingai, M.; Klein, F.; Gazumyan, A.; Golijanin, J.; Donaldson, M.; et al. Early antibody therapy can induce long-lasting immunity to SHIV. Nature 2017, 543, 559-563. [CrossRef] [PubMed]

63. Bar, K.J.; Sneller, M.C.; Harrison, L.J.; Justement, J.S.; Overton, E.T.; Petrone, M.E.; Salantes, D.B.; Seamon, C.A.; Scheinfeld, B.; Kwan, R.W.; et al. Effect of HIV Antibody VRC01 on Viral Rebound after Treatment Interruption. N. Engl. J. Med. 2016, 375, 2037-2050. [CrossRef] [PubMed]

64. Jackson, H.J.; Rafiq, S.; Brentjens, R.J. Driving CAR T-cells forward. Nat. Rev. Clin. Oncol. 2016, 13, 370-383. [CrossRef] [PubMed]

65. Wagner, T.A. Quarter Century of Anti-HIV CAR T Cells. Curr. HIV/AIDS Rep. 2018, 15, 147-154. [CrossRef] [PubMed]

66. Kim, G.B.; Hege, K.; Riley, J.L. CAR Talk: How Cancer-Specific CAR T Cells Can Instruct How to Build CAR T Cells to Cure HIV. Front. Immunol. 2019, 10, 2310. [CrossRef]

67. Herzig, E.; Kim, K.C.; Packard, T.A.; Vardi, N.; Schwarzer, R.; Gramatica, A.; Deeks, S.G.; Williams, S.R.; Landgraf, K.; Killeen, N.; et al. Attacking Latent HIV with convertibleCAR-T Cells, a Highly Adaptable Killing Platform. Cell 2019, 179, 880-894.e810. [CrossRef]

68. Liu, B.; Zhang, W.; Zhang, H. Development of CAR-T cells for long-term eradication and surveillance of HIV-1 reservoir. Curr. Opin. Virol. 2019, 38, 21-30. [CrossRef]

69. Abner, E.; Jordan, A. HIV "shock and kill" therapy: In need of revision. Antiviral Res. 2019, 166, 19-34. [CrossRef]

70. Cillo, A.R.; Sobolewski, M.D.; Bosch, R.J.; Fyne, E.; Piatak, M., Jr.; Coffin, J.M.; Mellors, J.W. Quantification of HIV-1 latency reversal in resting CD4+ T cells from patients on suppressive antiretroviral therapy. Proc. Natl. Acad. Sci. USA 2014, 111, 7078-7083. [CrossRef]

71. Archin, N.M.; Espeseth, A.; Parker, D.; Cheema, M.; Hazuda, D.; Margolis, D.M. Expression of latent HIV induced by the potent HDAC inhibitor suberoylanilide hydroxamic acid. AIDS Res. Hum. Retroviruses 2009, 25, 207-212. [CrossRef] [PubMed]

72. Archin, N.M.; Liberty, A.L.; Kashuba, A.D.; Choudhary, S.K.; Kuruc, J.D.; Crooks, A.M.; Parker, D.C.; Anderson, E.M.; Kearney, M.F.; Strain, M.C.; et al. Administration of vorinostat disrupts HIV-1 latency in patients on antiretroviral therapy. Nature 2012, 487, 482-485. [CrossRef] [PubMed] 
73. Wu, G.; Swanson, M.; Talla, A.; Graham, D.; Strizki, J.; Gorman, D.; Barnard, R.J.; Blair, W.; Sogaard, O.S.; Tolstrup, M.; et al. HDAC inhibition induces HIV-1 protein and enables immune-based clearance following latency reversal. JCI Insight. 2017, 2. [CrossRef] [PubMed]

74. Archin, N.M.; Kirchherr, J.L.; Sung, J.A.; Clutton, G.; Sholtis, K.; Xu, Y.; Allard, B.; Stuelke, E.; Kashuba, A.D.; Kuruc, J.D.; et al. Interval dosing with the HDAC inhibitor vorinostat effectively reverses HIV latency. J. Clin. Investig. 2017, 127, 3126-3135. [CrossRef]

75. Jones, R.B.; O'Connor, R.; Mueller, S.; Foley, M.; Szeto, G.L.; Karel, D.; Lichterfeld, M.; Kovacs, C.; Ostrowski, M.A.; Trocha, A.; et al. Histone deacetylase inhibitors impair the elimination of HIV-infected cells by cytotoxic T-lymphocytes. PLoS Pathog. 2014, 10, e1004287. [CrossRef]

76. Subramanian, S.; Bates, S.E.; Wright, J.J.; Espinoza-Delgado, I.; Piekarz, R.L. Clinical Toxicities of Histone Deacetylase Inhibitors. Pharmaceuticals (Basel) 2010, 3, 2751-2767. [CrossRef]

77. Sung, J.A.; Lam, S.; Garrido, C.; Archin, N.; Rooney, C.M.; Bollard, C.M.; Margolis, D.M. Expanded cytotoxic T-cell lymphocytes target the latent HIV reservoir. J. Infect. Dis. 2015, 212, 258-263. [CrossRef]

78. Imai, K.; Togami, H.; Okamoto, T. Involvement of histone H3 lysine 9 (H3K9) methyltransferase G9a in the maintenance of HIV-1 latency and its reactivation by BIX01294. J. Biol. Chem. 2010, 285, 16538-16545. [CrossRef]

79. Boehm, D.; Jeng, M.; Camus, G.; Gramatica, A.; Schwarzer, R.; Johnson, J.R.; Hull, P.A.; Montano, M.; Sakane, N.; Pagans, S.; et al. SMYD2-Mediated Histone Methylation Contributes to HIV-1 Latency. Cell Host Microbe 2017, 21, 569-579.e566. [CrossRef]

80. Friedman, J.; Cho, W.K.; Chu, C.K.; Keedy, K.S.; Archin, N.M.; Margolis, D.M.; Karn, J. Epigenetic silencing of HIV-1 by the histone H3 lysine 27 methyltransferase enhancer of Zeste 2. J. Virol. 2011, 85, 9078-9089. [CrossRef]

81. Cary, D.C.; Fujinaga, K.; Peterlin, B.M. Molecular mechanisms of HIV latency. J. Clin. Investig. 2016, 126, 448-454. [CrossRef] [PubMed]

82. Conrad, R.J.; Fozouni, P.; Thomas, S.; Sy, H.; Zhang, Q.; Zhou, M.M.; Ott, M. The Short Isoform of BRD4 Promotes HIV-1 Latency by Engaging Repressive SWI/SNF Chromatin-Remodeling Complexes. Mol. Cell 2017, 67, 1001-1012.e1006. [CrossRef] [PubMed]

83. Laird, G.M.; Bullen, C.K.; Rosenbloom, D.I.; Martin, A.R.; Hill, A.L.; Durand, C.M.; Siliciano, J.D.; Siliciano, R.F. Ex vivo analysis identifies effective HIV-1 latency-reversing drug combinations. J. Clin. Investig. 2015, 125, 1901-1912. [CrossRef] [PubMed]

84. Knights, H.D.J. A Critical Review of the Evidence Concerning the HIV Latency Reversing Effect of Disulfiram, the Possible Explanations for Its Inability to Reduce the Size of the Latent Reservoir In Vivo, and the Caveats Associated with Its Use in Practice. AIDS Res. Treat 2017, 2017, 8239428. [CrossRef] [PubMed]

85. Doyon, G.; Zerbato, J.; Mellors, J.W.; Sluis-Cremer, N. Disulfiram reactivates latent HIV-1 expression through depletion of the phosphatase and tensin homolog. AIDS 2013, 27, F7-F11. [CrossRef]

86. Elliott, J.H.; McMahon, J.H.; Chang, C.C.; Lee, S.A.; Hartogensis, W.; Bumpus, N.; Savic, R.; Roney, J.; Hoh, R.; Solomon, A.; et al. Short-term administration of disulfiram for reversal of latent HIV infection: A phase 2 dose-escalation study. Lancet HIV 2015, 2, e520-e529. [CrossRef]

87. Spivak, A.M.; Andrade, A.; Eisele, E.; Hoh, R.; Bacchetti, P.; Bumpus, N.N.; Emad, F.; Buckheit, R., 3rd; McCance-Katz, E.F.; Lai, J.; et al. A pilot study assessing the safety and latency-reversing activity of disulfiram in HIV-1-infected adults on antiretroviral therapy. Clin. Infect. Dis. 2014, 58, 883-890. [CrossRef]

88. Bullen, C.K.; Laird, G.M.; Durand, C.M.; Siliciano, J.D.; Siliciano, R.F. New ex vivo approaches distinguish effective and ineffective single agents for reversing HIV-1 latency in vivo. Nat. Med. 2014, 20, 425-429. [CrossRef]

89. Gutierrez, C.; Serrano-Villar, S.; Madrid-Elena, N.; Perez-Elias, M.J.; Martin, M.E.; Barbas, C.; Ruiperez, J.; Munoz, E.; Munoz-Fernandez, M.A.; Castor, T.; et al. Bryostatin-1 for latent virus reactivation in HIV-infected patients on antiretroviral therapy. AIDS 2016, 30, 1385-1392. [CrossRef]

90. Martinez-Bonet, M.; Clemente, M.I.; Serramia, M.J.; Munoz, E.; Moreno, S.; Munoz-Fernandez, M.A. Synergistic Activation of Latent HIV-1 Expression by Novel Histone Deacetylase Inhibitors and Bryostatin-1. Sci. Rep. 2015, 5, 16445. [CrossRef]

91. Kupchan, S.M.; Uchida, I.; Branfman, A.R.; Dailey, R.G., Jr.; Fei, B.Y. Antileukemic principles isolated from euphorbiaceae plants. Science 1976, 191, 571-572. [CrossRef] [PubMed] 
92. Pandelo Jose, D.; Bartholomeeusen, K.; da Cunha, R.D.; Abreu, C.M.; Glinski, J.; da Costa, T.B.; Bacchi Rabay, A.F.; Pianowski Filho, L.F.; Dudycz, L.W.; Ranga, U.; et al. Reactivation of latent HIV-1 by new semi-synthetic ingenol esters. Virology 2014, 462-463, 328-339. [CrossRef]

93. Warrilow, D.; Gardner, J.; Darnell, G.A.; Suhrbier, A.; Harrich, D. HIV type 1 inhibition by protein kinase C modulatory compounds. AIDS Res. Hum. Retroviruses 2006, 22, 854-864. [CrossRef] [PubMed]

94. Jiang, G.; Mendes, E.A.; Kaiser, P.; Wong, D.P.; Tang, Y.; Cai, I.; Fenton, A.; Melcher, G.P.; Hildreth, J.E.; Thompson, G.R.; et al. Synergistic Reactivation of Latent HIV Expression by Ingenol-3-Angelate, PEP005, Targeted NF-kB Signaling in Combination with JQ1 Induced p-TEFb Activation. PLoS Pathog. 2015, 11, e1005066. [CrossRef] [PubMed]

95. Gama, L.; Abreu, C.M.; Shirk, E.N.; Price, S.L.; Li, M.; Laird, G.M.; Pate, K.A.; Wietgrefe, S.W.; O'Connor, S.L.; Pianowski, L.; et al. Reactivation of simian immunodeficiency virus reservoirs in the brain of virally suppressed macaques. AIDS 2017, 31, 5-14. [CrossRef] [PubMed]

96. Dental, C.; Proust, A.; Ouellet, M.; Barat, C.; Tremblay, M.J. HIV-1 Latency-Reversing Agents Prostratin and Bryostatin-1 Induce Blood-Brain Barrier Disruption/Inflammation and Modulate Leukocyte Adhesion/Transmigration. J. Immunol. 2017, 198, 1229-1241. [CrossRef]

97. Brogdon, J.; Ziani, W.; Wang, X.; Veazey, R.S.; Xu, H. In vitro effects of the small-molecule protein kinase C agonists on HIV latency reactivation. Sci. Rep. 2016, 6, 39032. [CrossRef]

98. Kawai, T.; Akira, S. The role of pattern-recognition receptors in innate immunity: Update on Toll-like receptors. Nat. Immunol. 2010, 11, 373-384. [CrossRef]

99. Macedo, A.B.; Novis, C.L.; Bosque, A. Targeting Cellular and Tissue HIV Reservoirs With Toll-Like Receptor Agonists. Front. Immunol. 2019, 10, 2450. [CrossRef]

100. Vibholm, L.; Schleimann, M.H.; Hojen, J.F.; Benfield, T.; Offersen, R.; Rasmussen, K.; Olesen, R.; Dige, A.; Agnholt, J.; Grau, J.; et al. Short-Course Toll-Like Receptor 9 Agonist Treatment Impacts Innate Immunity and Plasma Viremia in Individuals With Human Immunodeficiency Virus Infection. Clin. Infect. Dis. 2017, 64, 1686-1695. [CrossRef]

101. Macedo, A.B.; Novis, C.L.; De Assis, C.M.; Sorensen, E.S.; Moszczynski, P.; Huang, S.H.; Ren, Y.; Spivak, A.M.; Jones, R.B.; Planelles, V.; et al. Dual TLR2 and TLR7 agonists as HIV latency-reversing agents. JCI Insight. 2018, 3. [CrossRef] [PubMed]

102. Lim, S.Y.; Osuna, C.E.; Hraber, P.T.; Hesselgesser, J.; Gerold, J.M.; Barnes, T.L.; Sanisetty, S.; Seaman, M.S.; Lewis, M.G.; Geleziunas, R.; et al. TLR7 agonists induce transient viremia and reduce the viral reservoir in SIV-infected rhesus macaques on antiretroviral therapy. Sci. Transl. Med. 2018, 10. [CrossRef] [PubMed]

103. Del Prete, G.Q.; Alvord, W.G.; Li, Y.; Deleage, C.; Nag, M.; Oswald, K.; Thomas, J.A.; Pyle, C.; Bosche, W.J.; Coalter, V.; et al. TLR7 agonist administration to SIV-infected macaques receiving early initiated cART does not induce plasma viremia. JCI Insight. 2019, 4. [CrossRef] [PubMed]

104. Borducchi, E.N.; Cabral, C.; Stephenson, K.E.; Liu, J.; Abbink, P.; Ng'ang'a, D.; Nkolola, J.P.; Brinkman, A.L.; Peter, L.; Lee, B.C.; et al. Ad26/MVA therapeutic vaccination with TLR7 stimulation in SIV-infected rhesus monkeys. Nature 2016, 540, 284-287. [CrossRef] [PubMed]

105. Borducchi, E.N.; Liu, J.; Nkolola, J.P.; Cadena, A.M.; Yu, W.H.; Fischinger, S.; Broge, T.; Abbink, P.; Mercado, N.B.; Chandrashekar, A.; et al. Antibody and TLR7 agonist delay viral rebound in SHIV-infected monkeys. Nature 2018, 563, 360-364. [CrossRef]

106. Bai, L.; Smith, D.C.; Wang, S. Small-molecule SMAC mimetics as new cancer therapeutics. Pharmacol Ther. 2014, 144, 82-95. [CrossRef]

107. Sun, S.C. The noncanonical NF-kappaB pathway. Immunol. Rev. 2012, 246, 125-140. [CrossRef]

108. Hattori, S.I.; Matsuda, K.; Tsuchiya, K.; Gatanaga, H.; Oka, S.; Yoshimura, K.; Mitsuya, H.; Maeda, K. Combination of a Latency-Reversing Agent With a Smac Mimetic Minimizes Secondary HIV-1 Infection in vitro. Front Microbiol. 2018, 9, 2022. [CrossRef]

109. Struzik, J.; Szulc-Dabrowska, L. Manipulation of Non-canonical NF-kappaB Signaling by Non-oncogenic Viruses. Arch. Immunol. Ther. Exp. (Warsz.) 2019, 67, 41-48. [CrossRef]

110. Kuo, H.H.; Ahmad, R.; Lee, G.Q.; Gao, C.; Chen, H.R.; Ouyang, Z.; Szucs, M.J.; Kim, D.; Tsibris, A.; Chun, T.W.; et al. Anti-apoptotic Protein BIRC5 Maintains Survival of HIV-1-Infected CD4(+) T Cells. Immunity 2018, 48, 1183-1194.e1185. [CrossRef] 
111. Pache, L.; Dutra, M.S.; Spivak, A.M.; Marlett, J.M.; Murry, J.P.; Hwang, Y.; Maestre, A.M.; Manganaro, L.; Vamos, M.; Teriete, P.; et al. BIRC2/cIAP1 Is a Negative Regulator of HIV-1 Transcription and Can Be Targeted by Smac Mimetics to Promote Reversal of Viral Latency. Cell Host Microbe 2015, 18, 345-353. [CrossRef] [PubMed]

112. Bobardt, M.; Kuo, J.; Chatterji, U.; Chanda, S.; Little, S.J.; Wiedemann, N.; Vuagniaux, G.; Gallay, P.A. The inhibitor apoptosis protein antagonist Debio 1143 Is an attractive HIV-1 latency reversal candidate. PLoS ONE 2019, 14, e0211746. [CrossRef] [PubMed]

113. Campbell, G.R.; Bruckman, R.S.; Chu, Y.L.; Trout, R.N.; Spector, S.A. SMAC Mimetics Induce Autophagy-Dependent Apoptosis of HIV-1-Infected Resting Memory CD4+ T Cells. Cell Host Microbe 2018, 24, 689-702.e687. [CrossRef] [PubMed]

114. Cummins, N.W.; Sainski, A.M.; Dai, H.; Natesampillai, S.; Pang, Y.P.; Bren, G.D.; de Araujo Correia, M.C.M.; Sampath, R.; Rizza, S.A.; O’Brien, D.; et al. Prime, Shock, and Kill: Priming CD4 T Cells from HIV Patients with a BCL-2 Antagonist before HIV Reactivation Reduces HIV Reservoir Size. J. Virol. 2016, 90, 4032-4048. [CrossRef]

115. Kim, Y.; Anderson, J.L.; Lewin, S.R. Getting the "Kill" into "Shock and Kill": Strategies to Eliminate Latent HIV. Cell Host Microbe 2018, 23, 14-26. [CrossRef]

116. Spivak, A.M.; Planelles, V. Novel Latency Reversal Agents for HIV-1 Cure. Annu. Rev. Med. 2018, 69, 421-436. [CrossRef]

117. Battivelli, E.; Dahabieh, M.S.; Abdel-Mohsen, M.; Svensson, J.P.; Da Silva, I.T.; Cohn, L.B.; Gramatica, A.; Deeks, S.; Greene, W.C.; Pillai, S.K.; et al. Distinct chromatin functional states correlate with HIV latency reactivation in infected primary $\mathrm{CD} 4(+) \mathrm{T}$ cells. Elife 2018, 7. [CrossRef]

118. Kaul, M.; Zheng, J.; Okamoto, S.; Gendelman, H.E.; Lipton, S.A. HIV-1 infection and AIDS: Consequences for the central nervous system. Cell Death Differ. 2005, 12 (Suppl. 1), 878-892. [CrossRef]

119. Day, C.L.; Kaufmann, D.E.; Kiepiela, P.; Brown, J.A.; Moodley, E.S.; Reddy, S.; Mackey, E.W.; Miller, J.D.; Leslie, A.J.; DePierres, C.; et al. PD-1 expression on HIV-specific T cells is associated with T-cell exhaustion and disease progression. Nature 2006, 443, 350-354. [CrossRef]

120. Infante, J.R.; Dees, E.C.; Olszanski, A.J.; Dhuria, S.V.; Sen, S.; Cameron, S.; Cohen, R.B. Phase I dose-escalation study of LCL161, an oral inhibitor of apoptosis proteins inhibitor, in patients with advanced solid tumors. J. Clin. Oncol. 2014, 32, 3103-3110. [CrossRef]

121. Bock, M.; Stoye, J.P. Endogenous retroviruses and the human germline. Curr. Opin. Genet. Dev. 2000, 10, 651-655. [CrossRef]

122. Groh, S.; Schotta, G. Silencing of endogenous retroviruses by heterochromatin. Cell Mol. Life Sci. 2017, 74, 2055-2065. [CrossRef] [PubMed]

123. Fletcher, C.V.; Staskus, K.; Wietgrefe, S.W.; Rothenberger, M.; Reilly, C.; Chipman, J.G.; Beilman, G.J.; Khoruts, A.; Thorkelson, A.; Schmidt, T.E.; et al. Persistent HIV-1 replication is associated with lower antiretroviral drug concentrations in lymphatic tissues. Proc. Natl. Acad. Sci. USA 2014, 111, 2307-2312. [CrossRef] [PubMed]

124. Martinez-Picado, J.; Deeks, S.G. Persistent HIV-1 replication during antiretroviral therapy. Curr. Opin. HIV AIDS 2016, 11, 417-423. [CrossRef] [PubMed]

125. Bai, X.; Jiang, Y. Key factors in mTOR regulation. Cell Mol. Life Sci. 2010, 67, 239-253. [CrossRef]

126. Heredia, A.; Amoroso, A.; Davis, C.; Le, N.; Reardon, E.; Dominique, J.K.; Klingebiel, E.; Gallo, R.C.; Redfield, R.R. Rapamycin causes down-regulation of CCR5 and accumulation of anti-HIV beta-chemokines: An approach to suppress R5 strains of HIV-1. Proc. Natl. Acad. Sci. USA 2003, 100, 10411-10416. [CrossRef]

127. Heredia, A.; Latinovic, O.; Gallo, R.C.; Melikyan, G.; Reitz, M.; Le, N.; Redfield, R.R. Reduction of CCR5 with low-dose rapamycin enhances the antiviral activity of vicriviroc against both sensitive and drug-resistant HIV-1. Proc. Natl. Acad. Sci. USA 2008, 105, 20476-20481. [CrossRef]

128. Roy, J.; Paquette, J.S.; Fortin, J.F.; Tremblay, M.J. The immunosuppressant rapamycin represses human immunodeficiency virus type 1 replication. Antimicrob. Agents Chemother. 2002, 46, 3447-3455. [CrossRef]

129. Besnard, E.; Hakre, S.; Kampmann, M.; Lim, H.W.; Hosmane, N.N.; Martin, A.; Bassik, M.C.; Verschueren, E.; Battivelli, E.; Chan, J.; et al. The mTOR Complex Controls HIV Latency. Cell Host Microbe 2016, 20, 785-797. [CrossRef]

130. Stock, P.G.; Barin, B.; Hatano, H.; Rogers, R.L.; Roland, M.E.; Lee, T.H.; Busch, M.; Deeks, S.G.; for Solid Organ Transplantation in, H.I.V.S.I. Reduction of HIV persistence following transplantation in HIV-infected kidney transplant recipients. Am. J. Transpl. 2014, 14, 1136-1141. [CrossRef] 
131. Martin, A.R.; Pollack, R.A.; Capoferri, A.; Ambinder, R.F.; Durand, C.M.; Siliciano, R.F. Rapamycin-mediated mTOR inhibition uncouples HIV-1 latency reversal from cytokine-associated toxicity. J. Clin. Investig. 2017, 127, 651-656. [CrossRef] [PubMed]

132. Kao, S.Y.; Calman, A.F.; Luciw, P.A.; Peterlin, B.M. Anti-termination of transcription within the long terminal repeat of HIV-1 by tat gene product. Nature 1987, 330, 489-493. [CrossRef] [PubMed]

133. Salerno, D.; Hasham, M.G.; Marshall, R.; Garriga, J.; Tsygankov, A.Y.; Grana, X. Direct inhibition of CDK9 blocks HIV-1 replication without preventing T-cell activation in primary human peripheral blood lymphocytes. Gene 2007, 405, 65-78. [CrossRef] [PubMed]

134. Sobhian, B.; Laguette, N.; Yatim, A.; Nakamura, M.; Levy, Y.; Kiernan, R.; Benkirane, M. HIV-1 Tat assembles a multifunctional transcription elongation complex and stably associates with the 7SK snRNP. Mol. Cell 2010, 38, 439-451. [CrossRef] [PubMed]

135. Nemeth, G.; Varga, Z.; Greff, Z.; Bencze, G.; Sipos, A.; Szantai-Kis, C.; Baska, F.; Gyuris, A.; Kelemenics, K.; Szathmary, Z.; et al. Novel, selective CDK9 inhibitors for the treatment of HIV infection. Curr. Med. Chem. 2011, 18, 342-358. [CrossRef] [PubMed]

136. Van Duyne, R.; Guendel, I.; Jaworski, E.; Sampey, G.; Klase, Z.; Chen, H.; Zeng, C.; Kovalskyy, D.; El Kouni, M.H.; Lepene, B.; et al. Effect of mimetic CDK9 inhibitors on HIV-1-activated transcription. J. Mol. Biol. 2013, 425, 812-829. [CrossRef]

137. Okamoto, M.; Hidaka, A.; Toyama, M.; Hosoya, T.; Yamamoto, M.; Hagiwara, M.; Baba, M. Selective inhibition of HIV-1 replication by the CDK9 inhibitor FIT-039. Antiviral Res. 2015, 123, 1-4. [CrossRef]

138. Medina-Moreno, S.; Dowling, T.C.; Zapata, J.C.; Le, N.M.; Sausville, E.; Bryant, J.; Redfield, R.R.; Heredia, A. Targeting of CDK9 with indirubin $3^{\prime}$-monoxime safely and durably reduces HIV viremia in chronically infected humanized mice. PLoS ONE 2017, 12, e0183425. [CrossRef]

139. Steens, J.M.; Scherrer, D.; Gineste, P.; Barrett, P.N.; Khuanchai, S.; Winai, R.; Ruxrungtham, K.; Tazi, J.; Murphy, R.; Ehrlich, H. Safety, Pharmacokinetics, and Antiviral Activity of a Novel HIV Antiviral, ABX464, in Treatment-Naive HIV-Infected Subjects in a Phase 2 Randomized, Controlled Study. Antimicrob. Agents Chemother. 2017, 61. [CrossRef]

140. Hayashi, T.; Jean, M.; Huang, H.; Simpson, S.; Santoso, N.G.; Zhu, J. Screening of an FDA-approved compound library identifies levosimendan as a novel anti-HIV-1 agent that inhibits viral transcription. Antiviral Res. 2017, 146, 76-85. [CrossRef]

141. Campos, N.; Myburgh, R.; Garcel, A.; Vautrin, A.; Lapasset, L.; Nadal, E.S.; Mahuteau-Betzer, F.; Najman, R.; Fornarelli, P.; Tantale, K.; et al. Long lasting control of viral rebound with a new drug ABX464 targeting Rev mediated viral RNA biogenesis. Retrovirology 2015, 12, 30. [CrossRef]

142. Rutsaert, S.; Steens, J.M.; Gineste, P.; Cole, B.; Kint, S.; Barrett, P.N.; Tazi, J.; Scherrer, D.; Ehrlich, H.J.; Vandekerckhove, L. Safety, tolerability and impact on viral reservoirs of the addition to antiretroviral therapy of ABX464, an investigational antiviral drug, in individuals living with HIV-1: A Phase IIa randomised controlled study. J. Virus Erad. 2019, 5, 10-22. [PubMed]

143. Llano, M.; Saenz, D.T.; Meehan, A.; Wongthida, P.; Peretz, M.; Walker, W.H.; Teo, W.; Poeschla, E.M. An essential role for LEDGF/p75 in HIV integration. Science 2006, 314, 461-464. [CrossRef] [PubMed]

144. Vandekerckhove, L.; Christ, F.; Van Maele, B.; De Rijck, J.; Gijsbers, R.; Van den Haute, C.; Witvrouw, M.; Debyser, Z. Transient and stable knockdown of the integrase cofactor LEDGF/p75 reveals its role in the replication cycle of human immunodeficiency virus. J. Virol. 2006, 80, 1886-1896. [CrossRef] [PubMed]

145. Christ, F.; Voet, A.; Marchand, A.; Nicolet, S.; Desimmie, B.A.; Marchand, D.; Bardiot, D.; Van der Veken, N.J.; Van Remoortel, B.; Strelkov, S.V.; et al. Rational design of small-molecule inhibitors of the LEDGF/p75-integrase interaction and HIV replication. Nat. Chem. Biol. 2010, 6, 442-448. [CrossRef] [PubMed]

146. Vranckx, L.S.; Demeulemeester, J.; Saleh, S.; Boll, A.; Vansant, G.; Schrijvers, R.; Weydert, C.; Battivelli, E.; Verdin, E.; Cereseto, A.; et al. LEDGIN-mediated Inhibition of Integrase-LEDGF/p75 Interaction Reduces Reactivation of Residual Latent HIV. EBioMedicine 2016, 8, 248-264. [CrossRef]

147. Debyser, Z.; Vansant, G.; Bruggemans, A.; Janssens, J.; Christ, F. Insight in HIV Integration Site Selection Provides a Block-and-Lock Strategy for a Functional Cure of HIV Infection. Viruses 2018, 11, 12. [CrossRef]

148. Sodroski, J.; Rosen, C.; Wong-Staal, F.; Salahuddin, S.Z.; Popovic, M.; Arya, S.; Gallo, R.C.; Haseltine, W.A. Trans-acting transcriptional regulation of human T-cell leukemia virus type III long terminal repeat. Science 1985, 227, 171-173. [CrossRef] 
149. Burnett, J.C.; Miller-Jensen, K.; Shah, P.S.; Arkin, A.P.; Schaffer, D.V. Control of stochastic gene expression by host factors at the HIV promoter. PLoS Pathog. 2009, 5, e1000260. [CrossRef]

150. Razooky, B.S.; Pai, A.; Aull, K.; Rouzine, I.M.; Weinberger, L.S. A hardwired HIV latency program. Cell 2015, 160, 990-1001. [CrossRef]

151. Weinberger, L.S.; Burnett, J.C.; Toettcher, J.E.; Arkin, A.P.; Schaffer, D.V. Stochastic gene expression in a lentiviral positive-feedback loop: HIV-1 Tat fluctuations drive phenotypic diversity. Cell 2005, 122, 169-182. [CrossRef] [PubMed]

152. Massari, S.; Sabatini, S.; Tabarrini, O. Blocking HIV-1 replication by targeting the Tat-hijacked transcriptional machinery. Curr. Pharm. Des. 2013, 19, 1860-1879. [CrossRef] [PubMed]

153. Mousseau, G.; Valente, S. Strategies to Block HIV Transcription: Focus on Small Molecule Tat Inhibitors. Biology (Basel) 2012, 1, 668-697. [CrossRef] [PubMed]

154. Mousseau, G.; Clementz, M.A.; Bakeman, W.N.; Nagarsheth, N.; Cameron, M.; Shi, J.; Baran, P.; Fromentin, R.; Chomont, N.; Valente, S.T. An analog of the natural steroidal alkaloid cortistatin A potently suppresses Tat-dependent HIV transcription. Cell Host Microbe 2012, 12, 97-108. [CrossRef]

155. Li, C.; Mousseau, G.; Valente, S.T. Tat inhibition by didehydro-Cortistatin A promotes heterochromatin formation at the HIV-1 long terminal repeat. Epigenetics Chromatin 2019, 12, 23. [CrossRef]

156. Mousseau, G.; Kessing, C.F.; Fromentin, R.; Trautmann, L.; Chomont, N.; Valente, S.T. The Tat Inhibitor Didehydro-Cortistatin A Prevents HIV-1 Reactivation from Latency. MBio 2015, 6, e00465. [CrossRef]

157. Kessing, C.F.; Nixon, C.C.; Li, C.; Tsai, P.; Takata, H.; Mousseau, G.; Ho, P.T.; Honeycutt, J.B.; Fallahi, M.; Trautmann, L.; et al. In Vivo Suppression of HIV Rebound by Didehydro-Cortistatin A, a "Block-and-Lock" Strategy for HIV-1 Treatment. Cell Rep. 2017, 21, 600-611. [CrossRef]

158. Mousseau, G.; Aneja, R.; Clementz, M.A.; Mediouni, S.; Lima, N.S.; Haregot, A.; Kessing, C.F.; Jablonski, J.A.; Thenin-Houssier, S.; Nagarsheth, N.; et al. Resistance to the Tat Inhibitor Didehydro-Cortistatin A Is Mediated by Heightened Basal HIV-1 Transcription. MBio 2019, 10. [CrossRef]

159. Sen, G.L.; Blau, H.M. A brief history of RNAi: The silence of the genes. FASEB J. 2006, 20, 1293-1299. [CrossRef]

160. Setten, R.L.; Rossi, J.J.; Han, S.P. The current state and future directions of RNAi-based therapeutics. Nat. Rev. Drug Discov. 2019, 18, 421-446. [CrossRef]

161. Stevenson, M. Dissecting HIV-1 through RNA interference. Nat. Rev. Immunol. 2003, 3, 851-858. [CrossRef] [PubMed]

162. Boden, D.; Pusch, O.; Lee, F.; Tucker, L.; Ramratnam, B. Human immunodeficiency virus type 1 escape from RNA interference. J. Virol. 2003, 77, 11531-11535. [CrossRef] [PubMed]

163. Das, A.T.; Brummelkamp, T.R.; Westerhout, E.M.; Vink, M.; Madiredjo, M.; Bernards, R.; Berkhout, B. Human immunodeficiency virus type 1 escapes from RNA interference-mediated inhibition. J. Virol. 2004, 78, 2601-2605. [CrossRef] [PubMed]

164. Westerhout, E.M.; Ooms, M.; Vink, M.; Das, A.T.; Berkhout, B. HIV-1 can escape from RNA interference by evolving an alternative structure in its RNA genome. Nucleic Acids Res. 2005, 33, 796-804. [CrossRef]

165. Bobbin, M.L.; Burnett, J.C.; Rossi, J.J. RNA interference approaches for treatment of HIV-1 infection. Genome Med. 2015, 7, 50. [CrossRef]

166. Kretova, O.V.; Fedoseeva, D.M.; Gorbacheva, M.A.; Gashnikova, N.M.; Gashnikova, M.P.; Melnikova, N.V.; Chechetkin, V.R.; Kravatsky, Y.V.; Tchurikov, N.A. Six Highly Conserved Targets of RNAi Revealed in HIV-1-Infected Patients from Russia Are Also Present in Many HIV-1 Strains Worldwide. Mol. Ther. Nucleic Acids 2017, 8, 330-344. [CrossRef]

167. Choi, J.G.; Bharaj, P.; Abraham, S.; Ma, H.; Yi, G.; Ye, C.; Dang, Y.; Manjunath, N.; Wu, H.; Shankar, P. Multiplexing seven miRNA-Based shRNAs to suppress HIV replication. Mol. Ther. 2015, 23, 310-320. [CrossRef]

168. Singh, S.K.; Gaur, R.K. Progress towards therapeutic application of RNA interference for HIV infection. BioDrugs 2009, 23, 269-276. [CrossRef]

169. Soejitno, A.; Wihandani, D.M.; Kuswardhani, T. The therapeutic potential of RNA interference in controlling HIV-1 replication. Acta Med. Indones. 2009, 41, 215-221.

170. Swamy, M.N.; Wu, H.; Shankar, P. Recent advances in RNAi-based strategies for therapy and prevention of HIV-1/AIDS. Adv. Drug Deliv. Rev. 2016, 103, 174-186. [CrossRef] 
171. DiGiusto, D.L.; Krishnan, A.; Li, L.; Li, H.; Li, S.; Rao, A.; Mi, S.; Yam, P.; Stinson, S.; Kalos, M.; et al. RNA-based gene therapy for HIV with lentiviral vector-modified CD34(+) cells in patients undergoing transplantation for AIDS-related lymphoma. Sci. Transl. Med. 2010, 2, 36ra43. [CrossRef] [PubMed]

172. Smith, I.; Greenside, P.G.; Natoli, T.; Lahr, D.L.; Wadden, D.; Tirosh, I.; Narayan, R.; Root, D.E.; Golub, T.R.; Subramanian, A.; et al. Evaluation of RNAi and CRISPR technologies by large-scale gene expression profiling in the Connectivity Map. PLoS Biol. 2017, 15, e2003213. [CrossRef] [PubMed]

173. Fellmann, C.; Lowe, S.W. Stable RNA interference rules for silencing. Nat. Cell Biol. 2014, 16, 10-18. [CrossRef] [PubMed]

174. McManus, W.R.; Bale, M.J.; Spindler, J.; Wiegand, A.; Musick, A.; Patro, S.C.; Sobolewski, M.D.; Musick, V.K.; Anderson, E.M.; Cyktor, J.C.; et al. HIV-1 in lymph nodes is maintained by cellular proliferation during antiretroviral therapy. J. Clin. Investig. 2019, 130, 4629-4642. [CrossRef]

175. Pardons, M.; Baxter, A.E.; Massanella, M.; Pagliuzza, A.; Fromentin, R.; Dufour, C.; Leyre, L.; Routy, J.P.; Kaufmann, D.E.; Chomont, N. Single-cell characterization and quantification of translation-competent viral reservoirs in treated and untreated HIV infection. PLoS Pathog. 2019, 15, e1007619. [CrossRef]

176. Wiegand, A.; Spindler, J.; Hong, F.F.; Shao, W.; Cyktor, J.C.; Cillo, A.R.; Halvas, E.K.; Coffin, J.M.; Mellors, J.W.; Kearney, M.F. Single-cell analysis of HIV-1 transcriptional activity reveals expression of proviruses in expanded clones during ART. Proc. Natl. Acad. Sci. USA 2017, 114, E3659-E3668. [CrossRef]

177. Stone, D.; Kiem, H.P.; Jerome, K.R. Targeted gene disruption to cure HIV. Curr. Opin. HIV AIDS 2013, 8 , 217-223. [CrossRef]

178. Maeder, M.L.; Gersbach, C.A. Genome-editing Technologies for Gene and Cell Therapy. Mol. Ther. 2016, 24, 430-446. [CrossRef]

179. Rogers, G.L.; Cannon, P.M. Gene Therapy Approaches to Human Immunodeficiency Virus and Other Infectious Diseases. Hematol. Oncol. Clin. North Am. 2017, 31, 883-895. [CrossRef]

180. Belfort, M.; Bonocora, R.P. Homing endonucleases: From genetic anomalies to programmable genomic clippers. Methods Mol. Biol. 2014, 1123, 1-26. [CrossRef]

181. Dhanasekaran, M.; Negi, S.; Sugiura, Y. Designer zinc finger proteins: Tools for creating artificial DNA-binding functional proteins. Acc. Chem. Res. 2006, 39, 45-52. [CrossRef] [PubMed]

182. Papworth, M.; Kolasinska, P.; Minczuk, M. Designer zinc-finger proteins and their applications. Gene 2006, 366, 27-38. [CrossRef] [PubMed]

183. Wright, D.A.; Thibodeau-Beganny, S.; Sander, J.D.; Winfrey, R.J.; Hirsh, A.S.; Eichtinger, M.; Fu, F.; Porteus, M.H.; Dobbs, D.; Voytas, D.F.; et al. Standardized reagents and protocols for engineering zinc finger nucleases by modular assembly. Nat. Protoc. 2006, 1, 1637-1652. [CrossRef] [PubMed]

184. Shim, G.; Kim, D.; Park, G.T.; Jin, H.; Suh, S.K.; Oh, Y.K. Therapeutic gene editing: Delivery and regulatory perspectives. Acta Pharmacol. Sin. 2017, 38, 738-753. [CrossRef] [PubMed]

185. Qu, X.; Wang, P.; Ding, D.; Li, L.; Wang, H.; Ma, L.; Zhou, X.; Liu, S.; Lin, S.; Wang, X.; et al. Zinc-finger-nucleases mediate specific and efficient excision of HIV-1 proviral DNA from infected and latently infected human T cells. Nucleic Acids Res. 2013, 41, 7771-7782. [CrossRef]

186. Wayengera, M. Proviral HIV-genome-wide and pol-gene specific zinc finger nucleases: Usability for targeted HIV gene therapy. Theor. Biol. Med. Model. 2011, 8, 26. [CrossRef]

187. Ji, H.; Lu, P.; Liu, B.; Qu, X.; Wang, Y.; Jiang, Z.; Yang, X.; Zhong, Y.; Yang, H.; Pan, H.; et al. Zinc-Finger Nucleases Induced by HIV-1 Tat Excise HIV-1 from the Host Genome in Infected and Latently Infected Cells. Mol. Ther. Nucleic Acids 2018, 12, 67-74. [CrossRef]

188. Eberhardy, S.R.; Goncalves, J.; Coelho, S.; Segal, D.J.; Berkhout, B.; Barbas, C.F., 3rd. Inhibition of human immunodeficiency virus type 1 replication with artificial transcription factors targeting the highly conserved primer-binding site. J. Virol. 2006, 80, 2873-2883. [CrossRef]

189. Kim, Y.S.; Kim, J.M.; Jung, D.L.; Kang, J.E.; Lee, S.; Kim, J.S.; Seol, W.; Shin, H.C.; Kwon, H.S.; Van Lint, C.; et al. Artificial zinc finger fusions targeting Sp1-binding sites and the trans-activator-responsive element potently repress transcription and replication of HIV-1. J. Biol. Chem. 2005, 280, 21545-21552. [CrossRef]

190. Segal, D.J.; Goncalves, J.; Eberhardy, S.; Swan, C.H.; Torbett, B.E.; Li, X.; Barbas, C.F., 3rd. Attenuation of HIV-1 replication in primary human cells with a designed zinc finger transcription factor. J. Biol. Chem. 2004, 279, 14509-14519. [CrossRef] 
191. Reynolds, L.; Ullman, C.; Moore, M.; Isalan, M.; West, M.J.; Clapham, P.; Klug, A.; Choo, Y. Repression of the HIV-1 5' LTR promoter and inhibition of HIV-1 replication by using engineered zinc-finger transcription factors. Proc. Natl. Acad. Sci. USA 2003, 100, 1615-1620. [CrossRef] [PubMed]

192. Deng, J.; Qu, X.; Lu, P.; Yang, X.; Zhu, Y.; Ji, H.; Wang, Y.; Jiang, Z.; Li, X.; Zhong, Y.; et al. Specific and Stable Suppression of HIV Provirus Expression In Vitro by Chimeric Zinc Finger DNA Methyltransferase 1. Mol. Ther. Nucleic Acids 2017, 6, 233-242. [CrossRef] [PubMed]

193. Wang, P.; Qu, X.; Wang, X.; Zhu, X.; Zeng, H.; Chen, H.; Zhu, H. Specific reactivation of latent HIV-1 with designer zinc-finger transcription factors targeting the HIV-1 5'-LTR promoter. Gene Ther. 2014, 21, 490-495. [CrossRef] [PubMed]

194. Bogdanove, A.J.; Schornack, S.; Lahaye, T. TAL effectors: Finding plant genes for disease and defense. Curr. Opin. Plant Biol. 2010, 13, 394-401. [CrossRef]

195. Samson, M.; Libert, F.; Doranz, B.J.; Rucker, J.; Liesnard, C.; Farber, C.M.; Saragosti, S.; Lapoumeroulie, C.; Cognaux, J.; Forceille, C.; et al. Resistance to HIV-1 infection in caucasian individuals bearing mutant alleles of the CCR-5 chemokine receptor gene. Nature 1996, 382, 722-725. [CrossRef]

196. Holt, N.; Wang, J.; Kim, K.; Friedman, G.; Wang, X.; Taupin, V.; Crooks, G.M.; Kohn, D.B.; Gregory, P.D.; Holmes, M.C.; et al. Human hematopoietic stem/progenitor cells modified by zinc-finger nucleases targeted to CCR5 control HIV-1 in vivo. Nat. Biotechnol. 2010, 28, 839-847. [CrossRef]

197. Didigu, C.A.; Wilen, C.B.; Wang, J.; Duong, J.; Secreto, A.J.; Danet-Desnoyers, G.A.; Riley, J.L.; Gregory, P.D.; June, C.H.; Holmes, M.C.; et al. Simultaneous zinc-finger nuclease editing of the HIV coreceptors ccr5 and cxcr4 protects CD4+ T cells from HIV-1 infection. Blood 2014, 123, 61-69. [CrossRef]

198. Tebas, P.; Stein, D.; Tang, W.W.; Frank, I.; Wang, S.Q.; Lee, G.; Spratt, S.K.; Surosky, R.T.; Giedlin, M.A.; Nichol, G.; et al. Gene editing of CCR5 in autologous CD4 T cells of persons infected with HIV. N. Engl. J. Med. 2014, 370, 901-910. [CrossRef]

199. Allers, K.; Schneider, T. CCR5Delta32 mutation and HIV infection: Basis for curative HIV therapy. Curr. Opin. Virol. 2015, 14, 24-29. [CrossRef]

200. Joung, J.K.; Sander, J.D. TALENs: A widely applicable technology for targeted genome editing. Nat. Rev. Mol. Cell Biol. 2013, 14, 49-55. [CrossRef]

201. Ebina, H.; Kanemura, Y.; Misawa, N.; Sakuma, T.; Kobayashi, T.; Yamamoto, T.; Koyanagi, Y. A high excision potential of TALENs for integrated DNA of HIV-based lentiviral vector. PLoS ONE 2015, 10, e0120047. [CrossRef] [PubMed]

202. Strong, C.L.; Guerra, H.P.; Mathew, K.R.; Roy, N.; Simpson, L.R.; Schiller, M.R. Damaging the Integrated HIV Proviral DNA with TALENs. PLoS ONE 2015, 10, e0125652. [CrossRef] [PubMed]

203. Mock, U.; Machowicz, R.; Hauber, I.; Horn, S.; Abramowski, P.; Berdien, B.; Hauber, J.; Fehse, B. mRNA transfection of a novel TAL effector nuclease (TALEN) facilitates efficient knockout of HIV co-receptor CCR5. Nucleic Acids Res. 2015, 43, 5560-5571. [CrossRef]

204. Liu, J.; Gaj, T.; Patterson, J.T.; Sirk, S.J.; Barbas, C.F., 3rd. Cell-penetrating peptide-mediated delivery of TALEN proteins via bioconjugation for genome engineering. PLOS ONE 2014, 9, e85755. [CrossRef]

205. Ru, R.; Yao, Y.; Yu, S.; Yin, B.; Xu, W.; Zhao, S.; Qin, L.; Chen, X. Targeted genome engineering in human induced pluripotent stem cells by penetrating TALENs. Cell Regen. (Lond.) 2013, 2, 5. [CrossRef] [PubMed]

206. Mussolino, C.; Morbitzer, R.; Lutge, F.; Dannemann, N.; Lahaye, T.; Cathomen, T. A novel TALE nuclease scaffold enables high genome editing activity in combination with low toxicity. Nucleic Acids Res. 2011, 39, 9283-9293. [CrossRef]

207. Shi, B.; Li, J.; Shi, X.; Jia, W.; Wen, Y.; Hu, X.; Zhuang, F.; Xi, J.; Zhang, L. TALEN-Mediated Knockout of CCR5 Confers Protection Against Infection of Human Immunodeficiency Virus. J. Acquir. Immune Defic. Syndr. 2017, 74, 229-241. [CrossRef]

208. Perdigao, P.; Gaj, T.; Santa-Marta, M.; Barbas, C.F., 3rd; Goncalves, J. Reactivation of Latent HIV-1 Expression by Engineered TALE Transcription Factors. PLoS ONE 2016, 11, e0150037. [CrossRef]

209. Wang, X.; Wang, P.; Fu, Z.; Ji, H.; Qu, X.; Zeng, H.; Zhu, X.; Deng, J.; Lu, P.; Zha, S.; et al. Designed transcription activator-like effector proteins efficiently induced the expression of latent HIV-1 in latently infected cells. AIDS Res. Hum. Retroviruses 2015, 31, 98-106. [CrossRef]

210. Geissler, R.; Hauber, I.; Funk, N.; Richter, A.; Behrens, M.; Renner, I.; Chemnitz, J.; Hofmann-Sieber, H.; Baum, H.; van Lunzen, J.; et al. Patient-adapted, specific activation of HIV-1 by customized TAL effectors (TALEs), a proof of principle study. Virology 2015, 486, 248-254. [CrossRef] 
211. Zych, A.O.; Bajor, M.; Zagozdzon, R. Application of Genome Editing Techniques in Immunology. Arch. Immunol. Ther. Exp. (Warsz.) 2018, 66, 289-298. [CrossRef] [PubMed]

212. Lino, C.A.; Harper, J.C.; Carney, J.P.; Timlin, J.A. Delivering CRISPR: A review of the challenges and approaches. Drug Deliv. 2018, 25, 1234-1257. [CrossRef] [PubMed]

213. Bloom, K.; Mussolino, C.; Arbuthnot, P. Transcription Activator-Like Effector (TALE) Nucleases and Repressor TALEs for Antiviral Gene Therapy. Curr. Stem Cell Rep. 2015, 1, 1-8. [CrossRef]

214. Ishino, Y.; Shinagawa, H.; Makino, K.; Amemura, M.; Nakata, A. Nucleotide sequence of the iap gene, responsible for alkaline phosphatase isozyme conversion in Escherichia coli, and identification of the gene product. J. Bacteriol. 1987, 169, 5429-5433. [CrossRef] [PubMed]

215. Sorek, R.; Kunin, V.; Hugenholtz, P. CRISPR-a widespread system that provides acquired resistance against phages in bacteria and archaea. Nat. Rev. Microbiol. 2008, 6, 181-186. [CrossRef]

216. Xiao, Q.; Guo, D.; Chen, S. Application of CRISPR/Cas9-Based Gene Editing in HIV-1/AIDS Therapy. Front Cell Infect. Microbiol. 2019, 9, 69. [CrossRef]

217. Gilbert, L.A.; Larson, M.H.; Morsut, L.; Liu, Z.; Brar, G.A.; Torres, S.E.; Stern-Ginossar, N.; Brandman, O.; Whitehead, E.H.; Doudna, J.A.; et al. CRISPR-mediated modular RNA-guided regulation of transcription in eukaryotes. Cell 2013, 154, 442-451. [CrossRef]

218. Charlesworth, C.T.; Deshpande, P.S.; Dever, D.P.; Camarena, J.; Lemgart, V.T.; Cromer, M.K.; Vakulskas, C.A.; Collingwood, M.A.; Zhang, L.; Bode, N.M.; et al. Identification of preexisting adaptive immunity to Cas9 proteins in humans. Nat. Med. 2019, 25, 249-254. [CrossRef]

219. Ebina, H.; Misawa, N.; Kanemura, Y.; Koyanagi, Y. Harnessing the CRISPR/Cas9 system to disrupt latent HIV-1 provirus. Sci. Rep. 2013, 3, 2510. [CrossRef]

220. Khalili, W.H.; Rafal, K.; Fan, Y.; Yonggang, Z.; Laura, C.; Fang, L.; Biao, L.; David, A.-C.; Yoelvis, G.-M.; Jonathan, K.; et al. RNA-directed gene editing specifically eradicates latent and prevents new HIV-1 infection. Proc. Natl. Acad. Sci. USA 2014. [CrossRef]

221. Belmonte, H.-K.L.; Ying, G.; Arturo, D.; John, M.; Yuta, T.; Mo, L.; Keiichiro, S.; Ruo, X.; Tomoaki, H.; Chan-Jung, C.; et al. Use of the CRISPR/Cas9 system as an intracellular defense against HIV-1 infection in human cells. Nat. Commun. 2015, 6, 6413. [CrossRef]

222. Wang, Q.; Liu, S.; Liu, Z.; Ke, Z.; Li, C.; Yu, X.; Chen, S.; Guo, D. Genome scale screening identification of SaCas9/gRNAs for targeting HIV-1 provirus and suppression of HIV-1 infection. Virus Res. 2018, 250, $21-30$. [CrossRef] [PubMed]

223. Ophinni, Y.; Inoue, M.; Kotaki, T.; Kameoka, M. CRISPR/Cas9 system targeting regulatory genes of HIV-1 inhibits viral replication in infected T-cell cultures. Sci. Rep. 2018, 8, 7784. [CrossRef]

224. Lebbink, R.J.; de Jong, D.C.; Wolters, F.; Kruse, E.M.; van Ham, P.M.; Wiertz, E.J.; Nijhuis, M. A combinational CRISPR/Cas9 gene-editing approach can halt HIV replication and prevent viral escape. Sci. Rep. 2017, 7, 41968. [CrossRef]

225. Kaminski, R.; Chen, Y.; Fischer, T.; Tedaldi, E.; Napoli, A.; Zhang, Y.; Karn, J.; Hu, W.; Khalili, K. Elimination of HIV-1 Genomes from Human T-lymphoid Cells by CRISPR/Cas9 Gene Editing. Sci. Rep. 2016, 6, 22555. [CrossRef] [PubMed]

226. Bella, R.; Kaminski, R.; Mancuso, P.; Young, W.B.; Chen, C.; Sariyer, R.; Fischer, T.; Amini, S.; Ferrante, P.; Jacobson, J.M.; et al. Removal of HIV DNA by CRISPR from Patient Blood Engrafts in Humanized Mice. Mol. Ther. Nucleic Acids 2018, 12, 275-282. [CrossRef] [PubMed]

227. Kaminski, R.; Bella, R.; Yin, C.; Otte, J.; Ferrante, P.; Gendelman, H.E.; Li, H.; Booze, R.; Gordon, J.; Hu, W.; et al. Excision of HIV-1 DNA by gene editing: A proof-of-concept in vivo study. Gene Ther. 2016, 23, 690-695. [CrossRef]

228. Yin, C.; Zhang, T.; Qu, X.; Zhang, Y.; Putatunda, R.; Xiao, X.; Li, F.; Xiao, W.; Zhao, H.; Dai, S.; et al. In Vivo Excision of HIV-1 Provirus by saCas9 and Multiplex Single-Guide RNAs in Animal Models. Mol. Ther. 2017, 25, 1168-1186. [CrossRef]

229. Dash, P.K.; Kaminski, R.; Bella, R.; Su, H.; Mathews, S.; Ahooyi, T.M.; Chen, C.; Mancuso, P.; Sariyer, R.; Ferrante, P.; et al. Sequential LASER ART and CRISPR Treatments Eliminate HIV-1 in a Subset of Infected Humanized Mice. Nat. Commun. 2019, 10, 2753. [CrossRef]

230. Yoder, K.E.; Bundschuh, R. Host Double Strand Break Repair Generates HIV-1 Strains Resistant to CRISPR/Cas9. Sci. Rep. 2016, 6, 29530. [CrossRef] 
231. Wang, Z.; Pan, Q.; Gendron, P.; Zhu, W.; Guo, F.; Cen, S.; Wainberg, M.A.; Liang, C. CRISPR/Cas9-Derived Mutations Both Inhibit HIV-1 Replication and Accelerate Viral Escape. Cell Rep. 2016, 15, 481-489. [CrossRef]

232. Wang, G.; Zhao, N.; Berkhout, B.; Das, A.T. CRISPR-Cas9 Can Inhibit HIV-1 Replication but NHEJ Repair Facilitates Virus Escape. Mol. Ther. 2016, 24, 522-526. [CrossRef] [PubMed]

233. Ueda, S.; Ebina, H.; Kanemura, Y.; Misawa, N.; Koyanagi, Y. Anti-HIV-1 potency of the CRISPR/Cas9 system insufficient to fully inhibit viral replication. Microbiol. Immunol. 2016, 60, 483-496. [CrossRef]

234. Wang, G.; Zhao, N.; Berkhout, B.; Das, A.T. A Combinatorial CRISPR-Cas9 Attack on HIV-1 DNA Extinguishes All Infectious Provirus in Infected T Cell Cultures. Cell Rep. 2016, 17, 2819-2826. [CrossRef] [PubMed]

235. Jiang, F.; Doudna, J.A. CRISPR-Cas9 Structures and Mechanisms. Annu. Rev. Biophys. 2017, 46, 505-529. [CrossRef] [PubMed]

236. Zhang, X.H.; Tee, L.Y.; Wang, X.G.; Huang, Q.S.; Yang, S.H. Off-target Effects in CRISPR/Cas9-mediated Genome Engineering. Mol. Ther. Nucleic Acids 2015, 4, e264. [CrossRef]

237. Ye, L.; Wang, J.; Beyer, A.I.; Teque, F.; Cradick, T.J.; Qi, Z.; Chang, J.C.; Bao, G.; Muench, M.O.; Yu, J.; et al. Seamless modification of wild-type induced pluripotent stem cells to the natural CCR5Delta32 mutation confers resistance to HIV infection. Proc. Natl. Acad. Sci. USA 2014, 111, 9591-9596. [CrossRef]

238. Li, C.; Guan, X.; Du, T.; Jin, W.; Wu, B.; Liu, Y.; Wang, P.; Hu, B.; Griffin, G.E.; Shattock, R.J.; et al. Inhibition of HIV-1 infection of primary CD4+ T-cells by gene editing of CCR5 using adenovirus-delivered CRISPR/Cas9. J. Gen. Virol. 2015, 96, 2381-2393. [CrossRef]

239. Xu, L.; Yang, H.; Gao, Y.; Chen, Z.; Xie, L.; Liu, Y.; Liu, Y.; Wang, X.; Li, H.; Lai, W.; et al. CRISPR/Cas9-Mediated CCR5 Ablation in Human Hematopoietic Stem/Progenitor Cells Confers HIV-1 Resistance In Vivo. Mol. Ther. 2017, 25, 1782-1789. [CrossRef]

240. Xiao, Q.; Chen, S.; Wang, Q.; Liu, Z.; Liu, S.; Deng, H.; Hou, W.; Wu, D.; Xiong, Y.; Li, J.; et al. CCR5 editing by Staphylococcus aureus Cas9 in human primary CD4(+) T cells and hematopoietic stem/progenitor cells promotes HIV-1 resistance and CD4(+) T cell enrichment in humanized mice. Retrovirology 2019, 16, 15. [CrossRef]

241. Hou, P.; Chen, S.; Wang, S.; Yu, X.; Chen, Y.; Jiang, M.; Zhuang, K.; Ho, W.; Hou, W.; Huang, J.; et al. Genome editing of CXCR4 by CRISPR/cas9 confers cells resistant to HIV-1 infection. Sci. Rep. 2015, 5, 15577. [CrossRef] [PubMed]

242. Wang, Q.; Chen, S.; Xiao, Q.; Liu, Z.; Liu, S.; Hou, P.; Zhou, L.; Hou, W.; Ho, W.; Li, C.; et al. Genome modification of CXCR4 by Staphylococcus aureus Cas 9 renders cells resistance to HIV-1 infection. Retrovirology 2017, 14, 51. [CrossRef] [PubMed]

243. Yu, S.; Yao, Y.; Xiao, H.; Li, J.; Liu, Q.; Yang, Y.; Adah, D.; Lu, J.; Zhao, S.; Qin, L.; et al. Simultaneous Knockout of CXCR4 and CCR5 Genes in CD4+ T Cells via CRISPR/Cas9 Confers Resistance to Both X4- and R5-Tropic Human Immunodeficiency Virus Type 1 Infection. Hum. Gene Ther. 2018, 29, 51-67. [CrossRef] [PubMed]

244. Dar, A.; Kollet, O.; Lapidot, T. Mutual, reciprocal SDF-1/CXCR4 interactions between hematopoietic and bone marrow stromal cells regulate human stem cell migration and development in NOD/SCID chimeric mice. Exp. Hematol. 2006, 34, 967-975. [CrossRef] [PubMed]

245. Kim, V.; Mears, B.M.; Powell, B.H.; Witwer, K.W. Mutant Cas9-transcriptional activator activates HIV-1 in U1 cells in the presence and absence of LTR-specific guide RNAs. Matters (Zur.) 2017, 2017. [CrossRef] [PubMed]

246. Saayman, S.M.; Lazar, D.C.; Scott, T.A.; Hart, J.R.; Takahashi, M.; Burnett, J.C.; Planelles, V.; Morris, K.V.; Weinberg, M.S. Potent and Targeted Activation of Latent HIV-1 Using the CRISPR/dCas9 Activator Complex. Mol. Ther. 2016, 24, 488-498. [CrossRef]

247. Limsirichai, P.; Gaj, T.; Schaffer, D.V. CRISPR-mediated Activation of Latent HIV-1 Expression. Mol. Ther. 2016, 24, 499-507. [CrossRef]

248. Ji, H.; Jiang, Z.; Lu, P.; Ma, L.; Li, C.; Pan, H.; Fu, Z.; Qu, X.; Wang, P.; Deng, J.; et al. Specific Reactivation of Latent HIV-1 by dCas9-SunTag-VP64-mediated Guide RNA Targeting the HIV-1 Promoter. Mol. Ther. 2016, 24, 508-521. [CrossRef]

249. Bialek, J.K.; Dunay, G.A.; Voges, M.; Schafer, C.; Spohn, M.; Stucka, R.; Hauber, J.; Lange, U.C. Targeted HIV-1 Latency Reversal Using CRISPR/Cas9-Derived Transcriptional Activator Systems. PLoS ONE 2016, 11, e0158294. [CrossRef] 
250. Zhang, Y.; Yin, C.; Zhang, T.; Li, F.; Yang, W.; Kaminski, R.; Fagan, P.R.; Putatunda, R.; Young, W.B.; Khalili, K.; et al. CRISPR/gRNA-directed synergistic activation mediator (SAM) induces specific, persistent and robust reactivation of the HIV-1 latent reservoirs. Sci. Rep. 2015, 5, 16277. [CrossRef]

251. Qu, D.; Li, C.; Sang, F.; Li, Q.; Jiang, Z.Q.; Xu, L.R.; Guo, H.J.; Zhang, C.; Wang, J.H. The variances of Sp1 and NF-kappaB elements correlate with the greater capacity of Chinese HIV-1 B'-LTR for driving gene expression. Sci. Rep. 2016, 6, 34532. [CrossRef] [PubMed]

252. Bogerd, H.P.; Kornepati, A.V.; Marshall, J.B.; Kennedy, E.M.; Cullen, B.R. Specific induction of endogenous viral restriction factors using CRISPR/Cas-derived transcriptional activators. Proc. Natl. Acad. Sci. USA 2015, 112, E7249-E7256. [CrossRef] [PubMed]

253. Zhang, Y.; Ozono, S.; Yao, W.; Tobiume, M.; Yamaoka, S.; Kishigami, S.; Fujita, H.; Tokunaga, K. CRISPR-mediated activation of endogenous BST-2/tetherin expression inhibits wild-type HIV-1 production. Sci. Rep. 2019, 9, 3134. [CrossRef] [PubMed]

254. Guha, T.K.; Wai, A.; Hausner, G. Programmable Genome Editing Tools and their Regulation for Efficient Genome Engineering. Comput. Struct. Biotechnol. J. 2017, 15, 146-160. [CrossRef]

255. Yu, K.R.; Natanson, H.; Dunbar, C.E. Gene Editing of Human Hematopoietic Stem and Progenitor Cells: Promise and Potential Hurdles. Hum. Gene Ther. 2016, 27, 729-740. [CrossRef] [PubMed]

256. Knipping, F.; Osborn, M.J.; Petri, K.; Tolar, J.; Glimm, H.; von Kalle, C.; Schmidt, M.; Gabriel, R. Genome-wide Specificity of Highly Efficient TALENs and CRISPR/Cas9 for T Cell Receptor Modification. Mol. Ther. Methods Clin. Dev. 2017, 4, 213-224. [CrossRef]

257. Guha, T.K.; Edgell, D.R. Applications of Alternative Nucleases in the Age of CRISPR/Cas9. Int J. Mol. Sci. 2017, 18, 2565. [CrossRef]

258. Straubeta, A.; Lahaye, T. Zinc fingers, TAL effectors, or Cas9-based DNA binding proteins: What's best for targeting desired genome loci? Mol. Plant 2013, 6, 1384-1387. [CrossRef]

259. Chevalier, B.S.; Stoddard, B.L. Homing endonucleases: Structural and functional insight into the catalysts of intron/intein mobility. Nucleic Acids Res. 2001, 29, 3757-3774. [CrossRef]

260. Stoddard, B.L. Homing endonucleases from mobile group I introns: Discovery to genome engineering. Mob DNA 2014, 5, 7. [CrossRef]

261. Daboussi, F.; Stoddard, T.J.; Zhang, F. Engineering Meganuclease for Precise Plant Genome Modification. In Engineering Meganuclease for Precise Plant Genome Modification. In Advances in New Technology for Targeted Modification of Plant Genomes; Feng Zhang, H.P., Thomson, J.G., Eds.; Springer Science+Business Media: New York, NY, USA, 2015; pp. 21-38. [CrossRef]

262. Waryah, C.B.; Moses, C.; Arooj, M.; Blancafort, P. Zinc Fingers, TALEs, and CRISPR Systems: A Comparison of Tools for Epigenome Editing. Methods Mol. Biol. 2018, 1767, 19-63. [CrossRef] [PubMed]

263. Mehta, A.; Haber, J.E. Sources of DNA double-strand breaks and models of recombinational DNA repair. Cold Spring Harb. Perspect. Biol. 2014, 6, a016428. [CrossRef] [PubMed]

264. Rodgers, K.; McVey, M. Error-Prone Repair of DNA Double-Strand Breaks. J. Cell Physiol. 2016, 231, $15-24$. [CrossRef] [PubMed]

265. Clarridge, K.E.; Blazkova, J.; Einkauf, K.; Petrone, M.; Refsland, E.W.; Justement, J.S.; Shi, V.; Huiting, E.D.; Seamon, C.A.; Lee, G.Q.; et al. Effect of analytical treatment interruption and reinitiation of antiretroviral therapy on HIV reservoirs and immunologic parameters in infected individuals. PLoS Pathog. 2018, 14, e1006792. [CrossRef]

(C) 2020 by the authors. Licensee MDPI, Basel, Switzerland. This article is an open access article distributed under the terms and conditions of the Creative Commons Attribution (CC BY) license (http://creativecommons.org/licenses/by/4.0/). 